\title{
A History of Marginalisation: Maori Women
}

by

Monique Gemmell

\begin{abstract}
A thesis
submitted to the Victoria University of Wellington

in partial fulfilment of the requirements for the degree of

Master of Education
\end{abstract}

Victoria University of Wellington

2013 
Page ii of 102 


\begin{abstract}
This thesis is a history of marginalisation as experienced by Maori women within New Zealand. My argument is that through the founding British Crown, the education system and Christianity, Maori women were marginalised (Pihama, 2001). My hypothesis is that once we understand how we were marginalised, we begin to liberate ourselves.

I seek to identify legislation and social phenomena that marginalised Maori women. These are the sorts of discourses led to assimilative, alienative and hegemonic outcomes for ori women. Moana Jackson refers to this form of marginalisation and its influences as, "the destruction of the Maori soul" (as cited by Mikaere, 1995, p. 138).

The consequences of marginalisation will highlight the importance of identity, matauranga Maori and the relevance of whenua to Maori women (Mikaere, 2003). In undertaking this task, I seek to answer how the New Zealand education system could contribute to emancipating Maori women.

By applying a Kaupapa Maori methodology (Smith, G. , 1997), an examination of how Maori women were effected by colonisation and imperialism will be explored. For this study, I have opted to utilise a qualitative approach in gathering and undertaking my research (Denzin \& Lincoln, 1984). The Kaupapa Maori methodology and a qualitative method enable me as a Maori woman to tell the story of our lived experiences as Maori women.
\end{abstract}

\title{
Keywords
}

Maori women, mana wahine, marginalisation, transformation, education 


\section{Acknowledgements}

First and foremost I offer my sincerest gratitude to my supervisor, Dr. Wally Penetito, whose patience and knowledge has supported me. Wally, you're teachings have and always will remain a positive influence in my life. To Victoria University, I thank you for the opportunity that I have been given in writing and studying at a Master level. My examiners, I thank you for your insight and clarity and I hope that I have strengthened my thesis through your review.

I would also like to thank Dr. Kath Irwin for her commitment and dedication to teaching me from the onset of my Masters journey. Without a doubt your passion and belief in Maori women has influenced my thesis choice.

This thesis would never have happened without the supportive working environment of the Koru Institute of Training and Education (KITE). To my company directors, my work colleagues, and all our students, thank you, your support has been overwhelming and without you I could not have done this.

I owe my deepest gratitude to my family. To my Mum and Dad; there are not words to be found that express my gratitude for your never-ending love, support and belief in me. To my dad, I was fortunate to have gained the genetic traits of logic and reasoning, to my mum I was bequeathed the art of challenging and standing up for myself. Without both your strengths I would not have achieved the things I have done in my life, I love you both.

To my husband; thank you for all the coffees and the late nights reading my thesis. You have been my rock throughout this process and have always held my hand. God gifted me with 5 daughters, Samantha, Victoria, Natasha, Isabella and Anastasia, thank you for being patient and giving me the strength to carry on, it is perhaps God's choice that I should write about women and only have daughters. But to my girls - always remember your whakapapa, hold on to the future- remember who you are and where you come from - Kia kaha. To my Nan; thank you, you have been one of the strongest influences in my life. I miss you every day and wish you were here, but having you in my heart has kept me strong and has influenced my journey.

Lastly, to my Mum and study buddy, Sharon Gemmell; I don't know how many times I wanted to give up, but just knowing you were up at the late hours of the night studying and sweating over your thesis gave me the strength to keep going. Mum you are the greatest inspiration in my life - you are living proof of mana wahine.

Thank you for all your support. 


\section{Table of Contents}

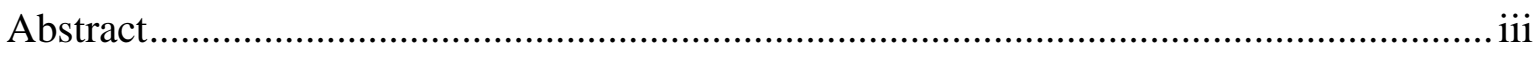

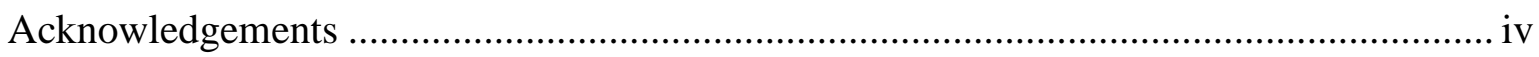

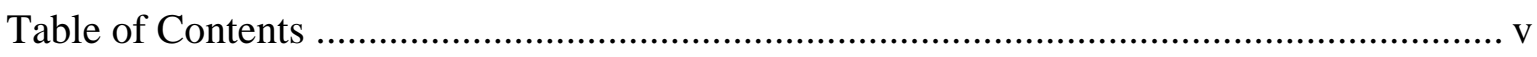

Chapter 1: Introduction ..................................................................................... 1

Chapter 2: $\quad$ Research Design And Methodology .......................................................... 5

Chapter 3: The Significance Of Maori Women ........................................................ 15

Chapter 4: Examining The Marginalisation Of Maori Women ..................................... 33

Chapter 5: Identity, A Sense Of Belonging And Matauranga Maori ............................... 55

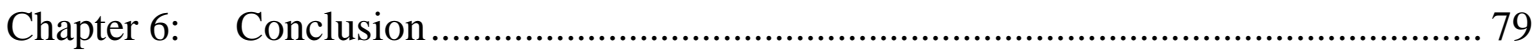

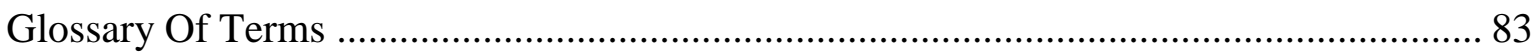

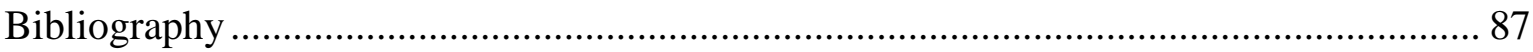





\section{Chapter 1: Introduction}

Topic

This thesis, A History of Marginalisation: Maori Women, is best defined as a thesis regarding how Maori women were excluded and made to feel inferior through the advancement of colonisation and imperialism within Aotearoa. It will reflect upon hegemonic processes of Western civilisation and the implementation of such processes within New Zealand. The effect of marginalisation is still evident in today's society with many Maori women struggling for freedom from colonisation (Pihama, 2001).

Understanding how colonisation affected our identity, our knowledge base and our sense of belonging, I offer education as a transformative tool for liberating Maori women.

\section{Aims of Research}

By applying a kaupapa Maori methodology (Smith, G. , 1997) to this thesis, I intend to explore how Maori women were made to feel inferior and often invisible through imperialism and colonisation. The use of kaupapa Maori as a methodology necessitates that the research is undertaken in a manner beneficial to Maori. Research undertaken by Maori for Maori should contribute to matauranga Maori and be emancipatory (Smith, L., 1999).

A qualitative approach to research, synonymous with kaupapa Maori, will be undertaken, enabling me to tell the story of how Maori women were made inferior, and in some cases invisible, through our lived experiences (Cronbach, 1975).

I hope to offer education as a transformative process. I will endeavour to answer the question - how can education contribute to liberating Maori women?

The focus areas for this thesis are:

1. the historical role and responsibilities of Maori women;

2. the impact colonisation and imperialism had upon Maori women; and

3. how education can be a transformative tool in contributing to the future aspirations of Maori and in particular, Maori women.

\section{Key Maori Definitions}

In writing my thesis, I intend to use Maori concepts and words and while these cannot be easily translated I will explain what these words mean in the context in which I have used them. A glossary of terms is also available to assist the reader.

European ethnographers applied the term Maori to define us as a people (Smith, L. , 1999). In this paper I also refer to Maori as the tangata whenua or in other terms, as the people of the land. For Maori today, the term Maori defines the Indigenous people of 
Aotearoa (ethnic grouping). As Maori, we continue to identify ourselves through iwi, hapu and whanau (Rangihau, 1975).

Our knowledge base, matauranga Maori, is informed through our worldview, te ao Maori (Mead, 2003). Matauranga Maori informs us as to how we know what we know. Matauranga Maori is our knowledge base. It stems from a time prior to mankind, a time from where the world and all livings things descend. As whare matauranga, or possessors of knowledge, Maori women were active transmitters of the Maori world view and knowledge base.

The word wahine is discussed in more detail in the third chapter of this thesis. Wahine does not only define us as Maori women, it permits us to identify ourselves throughout times in our lives. The position of wahine, as Maori women exists not statically, but as a process of evolution (Pihama, 2001). As whare tangata, or as translated, the housing of the human species, Maori women were respected for their ability to ensure the future of the iwi (Law Commission - Te Aka Matua O Te Ture, 1999).

Mana is described as power, authority, status, prestige and integrity. Mana cannot be possessed or generated by an individual; it is bequeathed upon an individual and/or groups (Henare, 1998). Therefore in the context of this thesis mana wahine is used to mean, Maori women's rights or our right to challenge and gain back our power, author, status and integrity (Pihama, 2001). Mana Tane is used to define the mana of Maori men and their rights (Winitana, 2008, p. 2).

Whenua is both the land and the placenta in which babies are carried through pregnancy (Mead, 2003).

Whakapapa is our genealogical and cultural identity. While whakapapa is often aligned with the concept of a family tree, whakapapa is greater than that, as Mead states, "whakapapa is a fundamental attribute and gift of birth" (2003, p.42).

Tikanga are the rules, our ethics and our morals. Tikanga is the customs, obligations and criterion by which we live our lives as Maori. (Mead, 2000)

Kawa is about process and differentiation between iwi, hapu and whanau. Kawa is the protocol (Mead, 2000).

\section{Other Definitions}

Marginalisation is a process where a dominant group of people push a minority group to the outer boundary of society (Ormond, Cram, \& Carter, 2006, p. 181). Akin with 
the definition of marginalisation is Foucault's (1964) concept of 'othering, a term used to make a group subordinate.

Colonisation is used to describe one nation assuming power over another. As an example, in the signing of the Treaty of Waitangi, colonisation took place in New Zealand (Said, 1994). The British took control over New Zealand.

As with colonisation, imperialism is a political and economic system. However, imperialism does not require the establishing of control over a country. Imperialism can be done through neighbouring empires and does not require for colonisation to take place (Said, 1994). An example of this was the coming of the Missionaries or the traders to New Zealand prior to New Zealand being colonised.

\section{Chapter Outline}

Chapter one outlines the topic and aims for this thesis. I have provided a brief description of key words and an insight into the methodology and methods I have chosen to use. Now I will give an overview of the layout and structure of the thesis.

Chapter two explains the methodology and methods used in my thesis. Kaupapa Maori methodology, subjectivity and ethics are discussed. A qualitative approach has been applied in writing this thesis and the reason for doing so will be explained.

The significance of Maori women is discussed in chapter three. This chapter is divided into two sections and explores the cosmological realm and pre-colonial roles of Maori women. Key concepts offered in discussing the cosmological realm include our metaphysical being and our creation story as Maori women. It explores the connection we have as Maori women with Papatuanuku through the cycle of life.

The latter part of this chapter explores our pre-colonial existence as Maori women our role as leaders, our role on the marae and our role as whare tangata and transmitters of matauranga Maori. The final component of this chapter looks at Maori women and their resistance to colonisation and resilience through roles that exemplify mana wahine.

In exploring our roles in the metaphysical world and from within a pre-colonial context it is hoped that our relationship as mana wahine with our mana tane is recognised as one of respect and reciprocity. We lived in harmony with each other and worked together to achieve the aspirations of Maori collectively.

Chapter four examines how colonisation and imperialism affected Maori women. In this regard marginalisation will be explored, a term meaning that a less dominant group is pushed to the periphery of society and denied their autonomy. While colonisation impacted upon Maori collectively, Maori women were further marginalised through sexism and 
patriarchy. A look at legislation, religion and education offers an insight into how colonisation marginalised Maori women when viewed through the lens of class, gender and race.

By providing a background for understanding how we were marginalised I hope that this chapter is viewed as self-determination and resistance to colonisation and imperialism, enabling transformative action to take place.

In chapter five, identity, a sense of belonging and matauranga Maori are discussed. The aim is to provide an understanding of the relevance of each of these concepts for Maori women. The final part of this chapter looks at a pedagogy that promotes transformation. The chapter has an emancipatory agenda and offers Maori women and educators an understanding of how education can contribute to transformation.

The final chapter is the conclusion. It summarises the argument and provides Maori women with an understanding of what has happened and how education can be an emancipative tool towards decolonisation. 


\section{Chapter 2: $\quad$ Research Design and Methodology}

\section{Introduction}

Part of the process of writing a thesis is to explain the methodology and to define the method. I have opted to use a qualitative approach to gathering information (Denzin \& Lincoln, 1984; Hughes, 2003). I have chosen this method as it allows me to use existing material such as literature, digital libraries and other available material, to tell the story of how Maori women were marginalised and then to connect the relevance of why identity, matauranga and a sense of belonging are crucial components of the New Zealand education system.

In relation to the methodology, kaupapa Maori requires me to engage in research that is for Maori, by Maori. One of the primary objectives of any research undertaken that uses a kaupapa Maori methodology is that the research contributes to the Maori worldview and that it is a useful tool for decolonising Maori (Pihama, Cram, \& Walker, 2002; Smith, L. , 1999).

A History of Marginalisation: Maori Women is a story that contributes to our knowledge as Maori. It explains how we were excluded and made to feel lesser through the processes of colonisation and imperialism. I then offer education as a process that could assist us in becoming de-colonised.

\section{Rationale}

The motivation and overall intention behind this thesis is to contribute to matauranga Maori and to offer an alternative angle to research that may benefit other researchers. I intend to provide a Maori women's perspective of marginalisation and, finally as an overall outcome, to give Maori a document that lifts the mana of Maori through transformation, emancipation, self-determination and decolonisation. In offering this thesis, I have outlined how I intend to undertake this:

1. To contribute to matauranga Maori;

Rigney (1999, p. 118) explains that Indigenous researchers should contribute to their cultural knowledge base as a fundamental factor to any indigenous model of research. 'Political integrity' is a process which makes Indigenous researchers accountable not just to their scholarly counterparts, but to their community. Pipi, Cram, Hawke, Hawke, Huriwai, Mataki, Milne, Morgan, Tuhaka, \& Tuuta (2000) concur that critical reflection of kaupapa Maori practices enables the sub-conscious to become conscious, therefore enabling a lesson to be learnt and knowledge to be added to the pool of research conducted by Maori for Maori.

2. To offer a research angle that may be useful to other researchers; 
Bowen (2005) explains that the researcher should contribute to research. Smith (2003) and Kiro (2000) tell us that useful research validates and legitimises Maori knowledge, language and culture. Smith (2003) also identifies that the user of any research has the onus of choosing whether or not to use the research and whether the purpose is supportive of a kaupapa Maori approach.

3. To provide an understanding from a Maori women's perspective of marginalisation and the connection between colonialism and imperialism;

Offering a research angle that is subjective and written using a kaupapa Maori methodology offers other researchers interested in this subject matter another pool of research to utilise (Bowen, 2005; Kiro, 2000). Kaupapa Maori is both a theory and praxis; it draws upon the lived realities and experiences of Maori (Sharples, 1998).

4. To engage in research that lifts the mana of Maori.

Any researcher using a kaupapa Maori methodology is responsible for ensuring that the research is done with the intent of regaining control over our resources and knowledge (Cram, 2001). Kaupapa Maori challenges hegemony and power structures from within New Zealand (Pihama, Cram, \& Walker, 2002). Durie (1998) accords this as a primary aim of "self-determination". Rigney (1999, p. 117) attributes this to "resistance" and "privileging Indigenous voices". Indigenous research should be emancipative and tell our story as Indigenous people.

\section{Theoretical Framework}

This thesis looks at how social and political practices in New Zealand have affected Maori women and our identity, sense of belonging and knowledge base. A critique of colonisation and imperialism within New Zealand offers the opportunity to analyse how this occurred. Through applying a framework that is culturally defined and guided by Indigenous principles enables me to engage in research that is respectful and conducive to positive change. Kaupapa Maori is a theoretical framework that enables me as a Maori woman to be part of the resistance towards the impact of Westernisation and its exploitation of Maori knowledge (Bargh, 2007). This thesis uses a kaupapa Maori framework to investigate how and why Maori women were marginalised from within a historical context specific to British settlement within New Zealand.

While some theorists might resist kaupapa Maori theory as a legitimate methodology, the increasing use of kaupapa Maori as a framework cannot be denied. It is a process for researching that enables Maori to think and act as Maori (Pihama, 2001). Kaupapa Maori as a theoretical framework is motivated by change or transformation. Kaupapa Maori evokes 
liberation (Smith, G., 1997). This stance is further supported on an international scale by authors such as bell hooks (1994) who describes theory as a tool to liberate and heal.

Whilst there continues to be some theorists who do not support kaupapa Maori as a research model, I am not of the same opinion. Elizabeth Rata (2006) disputes that kaupapa Maori is liberating and cautions that kaupapa Maori is an alternative form of oppression, one she terms as 'tribal elite'. Rata (2006) goes further to attribute kaupapa Maori as being 'undemocratic', meaning that it can be seen as inequitable. I do not agree with Rata and concur with the increasing number of scholars who contest these statements (Smith, G. 1997, Smith, L. 1999, Walker, S. 1996).

\section{Kaupapa Maori}

Kaupapa Maori is an Indigenous methodology (Kiro, 2000). Like many Indigenous peoples, Maori are calling for research that enables self-determination and liberation (Rigney, 1999; Smith, G. , 1997). Maori frustration regarding traditional research methodologies and their attributing effects and outcomes have been fundamental in Maori developing their own appreciation for research (Cram, 2001). I chose to use kaupapa Maori because it sets me inside the parameters of colonisation, asking me to define who I am, what I stand for and how the multiple layers of my value system are developed. A Maori way of life encapsulates our creation as Maori, our journey to Aotearoa, our tupuna, our whakapapa, our kuia and kaumatua and our babies. In this sense, kaupapa Maori is about our past and our future. As Maori, it is decolonising and transformative in action, reasserting our knowledge and worldviews (Kiro, 2000; Smith, L. , 2006; Smith, G. , 1997).

As Indigenous researchers we are reminded that one of the tenets is the epistemic challenge of Indigenous theorists to convey to the Western academy Indigenous knowledge. It is a process that confronts Western knowledge and in turn must endure the same process of critique, inclusive of criticism and self-reflection (Rewi, 2010). Williams (2010) reminds us that much of the past history written about Indigenous peoples is warped by the lack of relevance many colonial researchers had due to their own worldviews and perceptions. This lack of relevance and denial of contextualising history, due to differing worldviews and alternative agendas has been significant in distorting Indigenous history. It is a matter which Indigenous researchers must be aware of. Caution must be given to the application of cultural appropriateness as many recorded documents are contradictory because of the lack of cultural appropriateness.

Kaupapa Maori is a distinctive Indigenous model of researching unique to Maori. It is transformative and proactive. It challenges "the political context of unequal power 
relations and associated structural impediments" (Pihama, Smith et al, 2004, p.10). As argued by Smith (2006) kaupapa Maori as a theory deals with how we frame and construct the way we think and act.

For a researcher, kaupapa Maori theory provides a 'culturally safe' framework for which Maori and Maori knowledge can actively engage within (Irwin, 1994). Kaupapa Maori is not a new theoretical framework and in fact it is recognised by many as a theory based on Maori epistemologies stemming from the metaphysical realm (Nepe, 1991; Sharples, 1998). It is an Indigenous body of knowledge that has been handed down to Maori through practical experiences, korero and our arts.

Kaupapa Maori theory locates us as Maori in our lived experiences and practices. It is about our cultural and historical realities as a people (Sharples, 1998). Kaupapa Maori is a theory that encourages transformative action through knowing what has happened and the effects which it has had upon us as a people. hooks (1994) discusses this very concept through her understanding of theory and the relevance to her own livelihood as an AfricanAmerican woman.

\section{Whose Truth}

This thesis is written based on my truth, a Maori woman's truth (Barnes, 2000). The relevance is in accordance to that truth. As a Maori women, it is about regaining our knowledge as Maori, it is about transformative action. Marsden (2003) explains that one can only give their truth and that as a person telling the story from the standpoint of a Maori worldview their truth must also consider the general consensus of Maori as truth.

Gramsci (1971) identifies hegemony (one of the many facets of colonisation) as a way of thinking, owned by a dominant group, and controlled by that group, in order to control a less dominant group. Kaupapa Maori is a counter hegemonic process (Barnes, 2000; Smith, G., 1997), which challenges Maori to critically analyse their needs, aspirations and preferences.

Rigney states, that on an international scale Indigenous models of research seek “... to determine what might be an appropriate response to delegitimate racist oppression in research and shift to a more empowering and self-determining outcome" (1999, p. 110).

Much research that speaks of the Maori world view has been incorrectly perceived and documented by 'outsiders' (Kiro, 2000). This research has been detrimental to Maori. For Maori women, the consequences have been both racist and sexist (Johnston \& Pihama, 1993). The dominance of Western theory and Western researchers of the past have left many inaccurate accounts of history for Maori and particular to this thesis, Maori women. It is this 
perceived notion of Maori being less dominant and Maori culture as merely a historical curiosity, associated with primitive 'savagery', that Smith (1999) attributes much of the racism within New Zealand. The past relationship between Maori and theorists has been a process imposed upon Maori causing many to still be resentful.

Kaupapa Maori engages Maori as 'insiders' (Smith, L. , 1999) and offers Maori a framework to analyse the "way in which dominant groups construct 'common sense' and 'facts' to provide justification for maintaining inequalities and oppression for Maori people" (Kiro, 2000, p. 31).

The use of kaupapa Maori as an academic theory continues to be questioned, yet many academics have addressed the question of what kaupapa Maori is, how it can be used in research, and why it is an important methodology for the emancipation of Maori (Bishop, 1998; Cram, 2001; Hudson, 2004; Smith, G., 2003; Smith, L., 2006). This thesis is my truth based on my perception of the world and my value system underpins it, not just in my writing but in my way of life and how I choose to live, how I choose to raise my children and what is important and what is not important to me as a Maori woman. It is written from a kaupapa Maori viewpoint.

\section{Defining Me}

Kaupapa Maori theory permits Maori researchers subjectivity (Kiro, 2000) and requires them to notify the reader outright of their locality within the research process. Constance Mellon (1990) affirms this stating that objective research works hard to abolish bias, while subjective research acknowledges and declares the personal bias. Marsden (2003) tells us that as Maori researching Maori, the research can only be subjective as it talks to our past and our experiences. Williams view differs again with the suggestion that Maori write from the stand point of 'Etmic', a system he has coined by integrating two approaches; emic - a subjective approach and etic - an objective approach. Williams states that it "requires an understanding of the world view from where the material originated" (2010, p. 122). Williams believes that the etic approach enables the objectivity that emic denies.

I have a post Graduate Diploma in adult education and professional development and currently work as a Career practitioner and Chief Executive Officer of a Maori private training establishment in Blenheim.

I am the mother of five daughters and a grandmother to a little girl and recently a grandson. As a whanau we choose to live in a similar way to the traditional papa kainga. While we live in an urban area we have four homes on the one property, and have four 
generations living within our papa kainga. We share the role of caring for our babies and we actively participate in teaching our babies to live as Maori.

I have been fortunate to have lived and breathed the concept of mana wahine, a term now widely used and theorised. I have been surrounded by strong Maori women and their leadership from within the context of my own whanau, hapu and iwi. It is this very fortunate livelihood that brings me to write this thesis. For many Maori women I have encountered there continues to be a repressive state of living that prohibits them the freedom of emancipation. Understanding how hegemony has affected so many of Maori women is crucial to moving forward and being the great women our tupuna intended us to be. I want my daughters and my granddaughter to have the freedom to be Maori women with mana, free from the negative consequences of colonisation. And for my grandson, I hope that respectful relationships with tane and wahine are part of his lived life.

\section{Limitations of Research}

It is argued that the subjectivity of a researcher using a qualitative methodology can be biased, insignificant, subjective and idiosyncratic based on the research being opinionative and reaction-based rather than specific (Bowen, 2005). Wolcott (1995) refutes this by explaining that subjectivity when it is acknowledged can contribute to research based on the values and theories of the researcher. As suitably quoted by Tolich, the use of a qualitative research method "values personal involvement and partiality (subjectivity)" (1999, p. 117).

By choosing to apply a kaupapa Maori methodology I am required to acknowledge my subjectivity from the onset. Erickson (1984, p. 61) refers to this acknowledgement of bias as "disciplined subjectivity," Cotterill \& Letherby (1994, p. 109) refer to it as "conscious subjectivity".

Whilst the limitations of this thesis are bound by my subjectivity, it is also enlightened by my subjectivity as a Maori woman. I am a Maori woman, writing about my history and my understanding of the world. Therefore, I concur that this paper is written for Maori by Maori (Kiro, 2000). The choice of methodology, kaupapa Maori requires that the values and theories as inferred by Wolcott (1995) are bound by Maori values and Maori theories; tikanga and kawa.

My argument is that early ethnographers, who were supposedly objective, were not objective at all. They told our history through their ethnographic and patriarchal lens. Their research about us as Maori women was based on their worldview and in turn, they defined our lives and knowledge against their worldview. 


\section{Ethical Consideration}

Given that it is almost impossible to be totally objective in any research, as all humans have preconceived notions and beliefs, ethical consideration becomes important (Bowen, 2005).

The acknowledgement of subjectivity is imperative under the principles of tikanga. It enlightens the reader as to the whakapapa links and establishes a relationship between the reader and the researcher (Bishop, 1996). Whakapapa also informs of the commitment to Maori under the principles of Whakawhanaungatanga and forms the collaborative relationship between the reader, researcher and Maori (Pihama, et al., 2002). In a respectful manner, under the principles of tikanga this is about manaakitanga (Pipi et al., 2000), it is about respectful and reciprocal relationships that obligate the researcher to do what is right by their people. The collective approach to doing research under the principles of tikanga is pre-eminent in the definition provided by Mead,

"Processes, procedures and consultation need to be correct so that in the

end everyone who is connected with the research project is enriched, empowered, enlightened and glad to have been a part of it" (2003, p. 318).

The investigation process requires that 'aroha' be shown in a manner that reflects tikanga. Often aroha is undermined by being defined as 'love', yet aroha is greater than just love (Smith, L., 2005). Aroha is a process of showing respect. Aroha, in this regard is to honour our people as a collective and to undertake research in a manner that is both respectful and meaningful.

A large part of the kaupapa Maori methodology is the ethics that benchmark the process. Hudson (2004) reminds us that kaupapa Maori researchers not only need to adhere to their disciplinary ethics, but also their own ethics.

The intrinsic requirements of applying a kaupapa Maori methodology requires that self-determination, decolonisation and social justice be at the forefront of research, as ethical guidelines for research (Hughes, 2003; Smith, G., 1997). As Maori, our ethics are underpinned by tikanga and kawa (Smith, L., 1999; Smith, G., 1997). Ethics for Maori are complex in that they have regard for tradition, whakapapa, situation of place and are dictated by moral and ethical behaviours and reasoning (Henare, 1998). Tikanga is the knowledge of the ways in which we do things as Maori. It is our method, our ethical standard; it is about exercising practices that inform how and who we are as a people. Tikanga underpins our being in a cultural sense. Mead defines "tikanga" as being 
"...a set of beliefs and practices associated with procedures to be followed in conducting the affairs of a group or an individual. These procedures, as established by precedents through time, are held to be ritually correct, are validated by usually more than one generation and are always subject to what a group or an individual is able to do..." (2000, p. 16).

Based on this thesis using a qualitative method and existing documentation, there is no need for ethical committee approval from the University. However as a Maori researcher ethics are paramount, and as a Maori woman, I choose to adhere to tikanga according to the way my tupuna, kuia and kaumatua have raised me.

\section{Qualitative Method}

I have chosen to use a qualitative approach to research throughout this thesis rather than a quantitative research method. Polkinghorne informs that, "Qualitative research is inquiry aimed at describing and clarifying human experience as it appears in people's lives" (2005, p. 137). In order to explain the how and why, it is required that social settings, events and overall happenings be investigated (Cronbach, 1975).

A quantitative approach regards the relevance of statistics and demographics as critical to the method. This thesis is about the environment and the people, therefore a qualitative approach is most suitable, as it is not intended as an analysis based on statistical data. Tolich explains that, "qualitative research is not interested in answering questions such as 'How many times...?'. It abstains from traditional quantitative procedures and, instead aims to get at 'qualities' that can then be used to interpret and explain behaviour" (1999, p. 115).

Qualitative research enables an interpretive and naturalistic approach to research (Denzin \& Lincoln, 1984; Hughes, 2003), drawing on impression, description and quotes (Tolich, 1999). I have read, compared and analysed existing documentation such as Government reports and legislation and current scholarly work to tell the story of Maori women and the impact colonisation and imperialism has had.

My approach includes descriptive research (Denzin \& Lincoln, 1984) permitting the utilisation of existing material to define the topic and sort a solution to how Maori women were marginalised and what effect it has had on us. This is done by using a narrative format to research (Cresswell, 1994; Cronbach, 1975). As defined by Polkinghorne, "Narrative descriptions exhibit human activity as purposeful engagement in the world. Narrative is the type of discourse that draws together diverse events, happenings and actions of human lives" 
(1995, p. 5). A narrative format to research gives the 'subjects' a voice, whereas traditional forms of debating research objectifies the 'subjects' (Polkinghorne, 1995). For Maori, a narrative process is natural. As Maori it is how we told our history.

\section{Data Analysis}

In collecting the evidence for writing this thesis, the process has required sorting evidence that explained the lived experience of Maori women (Polkinghorne, 2005). This analysis has enabled excerpts from a collation of data to tell the story of how Maori women were marginalised.

Part of the way descriptive and explanatory research will be conducted is through describing the social perception and the differing concepts between Maori and European ways of life in the early history of colonisation within Aotearoa. The process of descriptive research involves theory and analysis, it involves social construction and historical accounts. Theory is a process that requires groups of people to be observed or described (Pihama, 2001). Analytical research will be undertaken providing for the ability to critically analyse the historical work of Ethnographers and Anthropologist. This will allow a critique of history that describes how colonisation and imperialism marginalised Maori women.

\section{Data Collection}

Since commencing my study, I have maintained a personal library that has enabled me to gather and sort documentation. The use of material gained from Victoria University, access to Te Wananga $\mathrm{O}$ Aotearoa web library facility, digital libraries and our work library, at the Koru Institute of Training and Education have been used to inform this research.

Information has been compiled according to the themes of each chapter and is used to support my opinion. Some critical analysis will be accorded to provide the opinion of other academics.

\section{Summary}

The benefit of this research (Eisner, 1991) is to provide a document that informs and enables an understanding of past events and situations through applying a qualitative method with the intent of becoming a useful document for the future of Maori women. Kaupapa Maori is a methodology designed to facilitate transformation for Maori through a counter hegemonic approach to research (Barnes, 2000).

Decolonisation is the primary objective of this thesis. Understanding how Maori women were marginalised through gender, race and class and in turn how education can 
contribute towards self-determination creates a forum for discussion on how we can utilise our knowledge and experience to transform histories misdoings (Durie, 1998).

In applying a kaupapa Maori methodology, I hope to contribute to research 'for Maori by Maori' by creating a document that contributes to matauranga Maori from a Maori woman's perspective and one that potentially offers another angle for further research. 


\section{Chapter 3: The Significance of Maori Women}

\section{Introduction}

This chapter is crucial to understanding why the metaphysical realm continues to inform our actions and sense of being as Maori women today. While the context of this chapter is specific to Maori women, the knowledge is not just ours as wahine. It is matauranga Maori - it is our worldview as Maori collectively. In a pre-colonial context Maori collectively had roles and responsibilities that sustained the livelihood of Maori (Mikaere, 2003). Upon European contact, this pre-colonial way of living was soon weakened in favour of Western ways of living.

Through matauranga Maori we are informed of our connectedness to the whenua and our identity as Maori. In a later chapter these issues will be linked to educational theories and validated as to why identity, matauranga Maori and place or sense of belonging continue to be important to the education system of New Zealand for Maori women.

Our metaphysical whakapapa was undermined by the Missionaries and their culture (Te Awekotuku, 1991). Our history and its whakapapa was reinterpreted, redefined and miscued by colonisation (Mikaere, 1994), having dire effect on matauranga Maori, Maori identity and our sense of belonging.

Pre-colonial contact Maori had respectful relationships where Maori men and women were crucial to the sustainability of iwi. Maori worked alongside each other for the betterment of whanau, hapu and iwi. Historically, our relationships were one of balance between social living and cohabitation with our environment (Mikaere, 2003).

Today many Maori women continue to suffer from the effects that marginalisation has had. Colonisation and imperialism are both processes and experiences that Maori women have endured. Through repressing Maori culture, practices, beliefs, and language, many Maori women have been socioeconomically disadvantaged and have had less access to resources such as health and education. Compared to non-Maori women, Maori women have lower educational attainment, lower income, and are more likely to be living in oneparent families (Law Commission - Te Aka Matua O Te Ture, 1999).

In the light of 'self-determination' and the privileging of an Indigenous voice (Rigney, 1999) I intend to demonstrate the role that Maori women had through matauranga Maori. This is a narrative that embraces Maori women as mana wahine. In the next chapter I will articulate how Maori women were marginalised through colonisation and imperialism. 


\section{Our Metaphysical Being - Our Spiritual Being}

This is the story of creation from a Maori worldview. From the inception of our metaphysical origins all living things stem from Papatuanuku (Earth mother) and Rangi (sky father), our parents (Jenkins \& Mountain Harte, 2011). Our worldview, as we are told by our tupuna is that our history and our story as Maori begins with our whakapapa, and it is from Papatuanuku and Rangi that we descend (Jenkins \& Mountain Harte, 2011). For Maori, our whakapapa is our genealogical journey from the spiritual realm to the physical world. Our whakapapa connects us to the whenua and forms part of our identity. This takes us back to the metaphysical realm, and leads us to the present and looks to the future. It is from Te Po to Te Ao Marama (the birth canal) that Maori women and our role begins (Mikaere, 2003).

\section{The Creation of Woman - Our Physical Being}

The significance of women throughout the Maori cosmological origins of mankind is critical to understanding the role of women in Maori society. While some authors accord the first existence of humankind to Tiki (Orbell, 1995), there is sufficient acknowledgment that Tane carved from the Earth, Hine-Ahu-One, who was the first humankind (Marsden, 2003; Mikaere, 2003). Orbell's acknowledgement of Tiki being the first human, could have been miscued by the fact that Tiki is also noted to be the male sexual organ and that the writing on this subject could have been misinterpreted to being a human form (Mikaere, 2003). Heuer (1969) relates Tiki to being of the spiritual realm.

Matauranga Maori tells us that Maori, and all other living things descend from the cohabitation of Mother Earth, Papatuanuku and Ranginui, Sky Father, or as Reverend Maori Marsden (2003) calls him Ranginui-awatea. Rangi was our male, and Papa our female (Orbell, 1995). It is from this unity that all living things derived, including Maori as physical beings.

Papatuanuku, or Papa - an abbreviated name meaning foundation or flat surface (Orbell, 1995), is charged with the responsibility of being our creator, our sustenance and our livelihood. She is our earth mother, the creator of our Kaitiaki and creator of humankind. Rangi (sky) was charged with creating the heavens, but when he looked below he was besotted with Papatuanuku and devoted his being to her (Marsden, 2003).

Rangi and Papa lived in darkness (Te Po) and clung to each other producing many offspring (Jenkins \& Mountain Harte, 2011; Mikaere, 2003). After some time, the children of Rangi and Papa became unhappy living in the darkness and decided to send Rangi back to the heavens (Jenkins \& Mountain Harte, 2011). Tane, the first born or as questioned by Reed (1983) as being one of the youngest of the relationship of Rangi and Papa, with the 
help of his siblings pushed his parents apart, causing the separation of his parents and permitting Te Ao o te Marama, or the world of light, to enter (Orbell, 1995; Reed, 1983). In this separation we see mist in the dawn; a sign of Papa's love for Rangi and the tears from the heaven. (Marsden, 2003; Reed, 1983).

After this separation, Tane, the Kaitiaki of the forest and the birds, enjoyed a peaceful life and was endowed with the obligations of his father Rangi to fulfil the development of the heavens (Marsden, 2003).

After a period of time Tane found himself yearning for something more and turned to his mother, Papatuanuku for help (Marsden, 2003; Mikaere, 2003; Reed, 1983). Tane wanted companionship. It is from here that the story of Maori women and our physical creation derives.

Tane, as requested by his mother, Papatuanuku visited Kura-waka, a tapu (sacred) place of virgins, a place where the seed of man is held (Reed, 1983). At Kura-waka (his mother's pubic region), Tane shaped the earth. Through the desire and passion within Tane and the help of his mother the first woman was created - Hine-ahu-one. Tane gave her life through a hongi or as loosely defined, 'gave her the breath of life' (Marsden, 2003; Mikaere, 2003). Papatuanuku "gifted to iwi the power of birth" (Kupenga, 1990, p. 8). Tane made Hine-ahu-one free to come and go as she pleased, she was to be his companion.

The minimal acknowledgement of Maori women within the cosmological history recorded by the early Missionaries and researchers is a display of the suppressive impact Christianity had upon Maori women (Mikaere, 1998). Elsdon Best (1954) informed readers that Maori cosmology, and in particular Maori systems of belief were questionable by comparison to Christianity (Mikaere, 1994). Our story of creation, and our Maori worldview is often undermined by the Bible and Christianity deeming Maori culture 'heathen' (Grey, 1906).

In the history books of New Zealand, Best recorded our creation story of human life, and the use of Papatuanuku' sexual organs as 'destructive' and as Best further remarked "associated with misfortune and inferiority" (1954, p. 47). Both statements undermine the role of Maori women and matauranga Maori. Best further undermined Maori women by reinterpreting our history stating that "man descended directly from the gods, while women had to be created from earth" (as cited by Mikaere, 2003, p. 86). Mikaere attacks Western religious beliefs and Western perceptions of male dominance terming them as "arrogant assumptions" (2003, p. 68) in relation to the interpretation of Maori mythology. 


\title{
Mother Earth and the Connection to Death
}

After Tane separated his parents, Rangi who was angry with the actions of his children suggested to Papa that the children be buried between them upon their deaths. Papa, who was also upset with her children for separating her from Rangi, said no to Rangi and told him that her children would return to her in death. Papatuanuku offered connectedness, a turangawaewae, a place to return to in death. Papa was their mother and her children would return to her (Mikaere, 2003). As Earth mother, Papatuanuku continues to nurture her children and grandchildren (mokopuna) in life and in death.

Tane and Hine-ahu-one conceived a child, (a female) named Hinetitama or as she is often referred to as Hine-nui-te-po, the Kaitiaki of souls (Jenkins \& Mountain Harte, 2011). Papatuanuku was a very influential figure in both Hine-ahu-one and Hine-nui-te-po lives and provided guidance and support to them both (Jenkins \& Mountain Harte, 2011). Hinenui-te-po as accorded by Mikaere (2003) sits waiting with love for us to return. At birth our whenua (placenta) is returned to Papatuanuku (Earth mother), where she nurtures us until we return to her in death (Papatuanuku) and back to Te Po.

Our story of creation informs us that life and death are a cycle, a process from which we are born to which we return to in death. From conception we wait in Te Po (darkness) until birth, where we enter Te Ao o Te Marama (coming into the light). In death we return to Te Po (Mikaere, 2003).

\section{Childbirth}

\author{
Ko te Korekore ka ahu mai ka po-takiwa \\ No ka Po-takiwa ka ahu mai Ao Katoa \\ Ka puta ki waho, ki roto i tenei Ao-marama \\ He takata hou ki te whaiao
}

Ki te Ao-marama

Tihei Mauri Ora!

$(\text { Tikao, 1939) })^{1}$

To a great extent the significance of Maori women is found in the ability to maintain and produce the lineage of whakapapa. We are whare tangata (house of mankind), we maintain the connection of whakapapa from the metaphysical realm to the physical realm. Maori women had great mana and were respected for their role as whare tangata, a role that

\footnotetext{
${ }^{1}$ Robinson, S. P. 308.
} 
saw whakapapa upheld. Our role as whare tangata, was recognised by iwi as a significant contribution to our sustainability, as Maori, as iwi, as hapu and as whanau.

Throughout pregnancy and child birth Maori women were protected (Mikaere, 2003). They were tapu; in the womb they held the future, and rituals were undertaken to protect the mother and her baby, both spiritually and physically (Heuer, 1969; Mikaere, 2003). The significance of tapu in relation to Maori women is connected to their ability to connect the spiritual and physical worlds together.

At the time of birth Maori women were taken to the whare kohanga (nesting house), where the midwives chanted and recited over the mother and pending baby. It is here that the mother gave birth and nursed her baby, under guidance (Jenkins \& Mountain Harte, 2011).

The status of tapu was removed only after the child was born and certain practices had been undertaken. These included karakia, a process called tohi (which the Missionaries likened to baptism) and food (Heuer, 1969). Only after these rituals were completed would the mother and child become noa (free from restriction).

Maori traditional methods of knowing affirm that the unborn child lay in the womb or Te Po (Mikaere, 2003). The child represented the unfolding of the universe, the struggle from darkness to light. Robinson (2005) attributes the knowledge of time and childbirth to the words expressed by Smith in 1913, where he used the words of the Takitimu Tohunga, Matorohanga, "All of these Po have been assigned to womankind, when they give birth to the 'germ of man' to the world" (Robinson, 2005, p. 308).

Robinson (2005) associates Maori knowledge of Te Po to the stages of pregnancy. The initial stage of pregnancy being Te Korekore: the ages of nothingness, where the existence is a void, a nothingness. From here the growth and development progresses to Te Po-tipu: the Night of growth or the dark night, the seed is fertilised. Next comes Te Po-rea: the Night of development of the night of water and so on until Te Po-tahuri-mai-ki-taiao: the Night of turning towards the revealed world, representing the coming into the light. The child is born from the darkness of the womb into the world of light, Te Ao Marama. Mikaere (2003) affirms these stages as cycles of conception, development and birth.

The afterbirth or whenua and umbilical cord represent the oronga or link to the child, and secured a good life and mana for the child (Robinson, 2005). They would be buried and returned to Earth mother (Papatuanuku), providing a sense of belonging, connectedness and identity for Maori. For Maori this practice is still active in today's society with many Maori continuing to return their whenua (afterbirth) to the whenua (Papatuanuku). 
It is in childbirth that the whakatauki, "he wahine, he whenua, ka ngaro te tangata" is enriched with the true essence of the mana of women in traditional times. Mikaere (2003, p. 33) cites Dr Rose Pere' translation as "humanity would be lost without women and land". The relationship of humankind and land are intertwined through the process of birth and death, it is our whakapapa. We were formed from the land and return to the land.

In times of colonisation, this practice of sacredness was almost diminished, Maori who choose to continue these practices had to do so 'underground' as it became illegal. The 1907 Tohunga Suppression Act saw the traditional Maori ritual of birth being outlawed and hospitals became the common practice for child birth. To add to the disparity and destruction, hospitals forbid the return of the afterbirth or whenua, destroying them in incinerators. Today, many Maori continue to suffer with this. It created a sense of loss and disconnectedness. The lack of understanding of the relationship between the whenua (afterbirth) and the whenua (land) has dislocated the identity of many Maori (Mikaere, 2003).

\section{The Story of the Haka}

The haka originates from our metaphysical realm. Ra, the Kaitiaki of the sun lay with his wife Hine-raumati, (the essence of summer) and they had a son named, Tanerore. It is said that Tanerore performed the haka for his mother, Hine-raumati. Today this can still been seen on a hot summers day when the light shimmers and is depicted in the haka in the action of the wiriwiri (Gardiner, 2005).

Yet the first known haka in the human realm is the story of Kae and Tinirau. It is a story of Maori women.

Kae was a Tohunga and Tinirau was a chief. Some say that Kae was the only survivor of a canoe that was blown offshore and that Tinirau saved him and cared for him (Mikaere, 2003). Others say that Tinirau wanted his son blessed and that Kae came as the Tohunga to perform the ritual (Gardiner, 2005).

As time came for Kae to leave, Tinirau offered him his pet whale, Tutunui, as a method of transport. Kae promised to take good care of the whale and gave his assurance to Tinirau that Tutunui would not come to harm. Kae did not keep his promise. Instead he beached Tutunui causing his death. Kae then placed the whale in the hangi pit and proceeded to cook him.

Tinirau began to worry that his pet whale had not returned. It was when the wind carried the smell of Tutunui's flesh being cooked that Tinirau realised the fate of his pet whale, Tutunui. In revenge, Tinirau sent a party of 40 women to seek revenge over the death 
of Tutunui. The women went in search for Kae. They had no idea what he looked like, but had been advised that he was a man with crooked and overlapping teeth.

On arrival at Kae's village, the women proceeded to play games in the hope of finding the man with crooked and overlapping teeth, but there was one man whose teeth they could not see. Determined to identify this man, the women proceeded to perform a poteteke (a form of haka), yet this man still remained unidentifiable. The women then decided to perform another haka, more explicit than the previous. With this haka, Kae was identified his laughter gave him away.

That night while the village slept, the women undertook to do karakia, putting the villagers into a deep sleep. It is here that they captured Kae and returned him to Tinirau where Kae met his fate (Mikaere, 2003).

Today there is an assumption that Maori women are not allowed to do the haka. It is an unfounded assumption, which I will elaborate on. While the infamous haka, "Ka Mate, Ka Mate", has been attributed to the All Blacks in their challenge on the rugby field, the origins offer an opportunity to view how Maori women in their role as mana wahine continue to be undermined by patriarchal misrepresentation of our history.

The story of Ka Mate, Ka Mate stems from the Ngati Toa/ Ngati Raukawa Rangatira, Te Rauparaha. In the early 1800's, the war-faring Te Rauparaha sought help in hiding from his enemy (the Waikato people). Te Rauparaha turned to another Rangatira named Wharerangi for help. Wharerangi advised Te Rauparaha to sit in the kumara pit, where he told his wife, Te Rangikoaea to sit above him. Te Rauparaha sat protected from his enemy under Te Rangikoaea (Mikaere, 2003). While he was under the protection of Te Rangikoaea, Te Rauparaha composed Ka Mate, Ka Mate.

In traditional times Maori women performed with men in haka, and in some haka Maori women took the lead role of pukana, performing at the front and challenging her roopu to support her (Heuer, 1969). Also let us not forget one of the most famous women's haka, "Ka Panapana", performed by Ngati Porou wahine and written by Moana Ngarimu. It is a haka which acknowledges the warrior spirit within women (Ihimaera, 2000).

\section{Pre-colonial Maori Women}

\section{He rereke te mana o te wahine, he rereke te mana o te tane}

Ko etahi mahi, e kore e taea e te tane, ko etahi mahi, e kore e taea e te wahine

It is important to state that pre-colonisation, Maori women and men had respectful relationships, where it was acknowledged that men had roles for which they were respected and this was reciprocated to women (Heuer, 1969). Survival in a pre-colonial context 
required that men and women worked together for the betterment of Maori. Maori women did not suffer oppression prior to European settlement in New Zealand. The role of Maori women was significant to the Maori community. Their mana came from birth rights and tupuna wahine, who were charged with the role of instilling mana through knowledge and whakapapa (Kupenga, 1990).

Prior to European settlement, members within the hapu participated in a variety of tasks. Rei (1993) provides an insight into the traditional roles of Maori women. Men and women collectively assisted with gardening and food gathering. Some more physically demanding, or potentially dangerous tasks were primarily undertaken by men, but women did assist with such tasks. An example given by Heuer (1969) is the cultivation of trees. Women would walk behind the men after they had cultivated and plant the new seedlings.

If a task was sacred and if that sacredness was to be potentially endangered, the role of responsibility was placed on the other gender. An example of this is the carving of whare and waka. This was tapu to women. Maori men fulfilled this duty, while Maori women were primarily responsible for weaving and clothing. Yet Maori men were known to make dog skin cloaks and to learn the art of weaving for the purpose of taniko and likewise there are wharenui that have been carved by Maori woman.

The context within which gender-specific duties were determined pre-colonial society was not sexist; roles were based on 'tapu', capability and the needs and practices of the whanau, hapu and iwi (Heuer, 1969). Maori women were equally valued as contributors to society.

\section{Maori Women Educating their Children}

Maori raised children collectively within the kainga. Child rearing was not solely a woman's job. Men were active in child-rearing and so were the elders (Jenkins \& Mountain Harte, 2011; Te Awekotuku, 1991). In many cases the primary role of child-rearing was done by the elders. This enabled the younger and fitter members of the kainga to work, including Maori women (Heuer, 1969). The hapu collectively were responsible for the growth and development of the children.

Educating the child started from conception. During pregnancy and after the birth the elders sang waiata and oriori to the child (Heuer, 1969; Jenkins \& Mountain Harte, 2011). These compositions were specific to the child and were a way of transmitting whakapapa, tribal links, metaphysical knowledge and tribal history. Our way as Maori educating our children helped to form the child's identity, worldview and values. This was also a method 
of ensuring the survival of te reo, matauranga, values and the narratives of whanau, hapu and iwi.

As Maori, pre-colonial contact, we did not write from within the European context of literacy, our literacy was visual, oral and artistically recorded. Historically, Maori knowledge was a practical and oral activity which enabled knowledge to be instilled for future generations (Jenkins \& Mountain Harte, 2011). Haka and poi were some of the pedagogies used to transmit knowledge that Maori women undertook in educating Maori children.

Learning was an active process where children learnt not only the art of physical movement, but also whakapapa, history and skills of oratory, the latter being a skill useful for roles such as public speaking (Heuer, 1969). Maori women are well recorded as being instrumental in maintaining this knowledge base (Mikaere, 1994). This method of learning and teaching was one that ensured the physical survival of Maori, as it told the stories of the people, the land and their whakapapa. Maori women are well recorded as composers, and orators of matauranga Maori, capable of conveying various forms of information ranging from birth to weaponry. Today these traditions are still active within Maori culture and continue to be upheld by Maori women (Mikaere, 2003).

Children learnt by working alongside other members in the kainga. They would observe and often assisted in some of the duties. (Heuer, 1969). Prior to a girl learning to weave, a ceremony took place to make her tapu. In this state she was not permitted to talk to anyone except the Tohunga and her instructor, she was expected to observe and learn. Here she learnt the rituals associated with cultivating and preparing materials, the application of weaving and the cautions needed when performing such tasks (Heuer, 1969).

\section{On the Marae}

The marae was and still remains an important place for Maori. All members of the kainga had a role to play. Some roles were given according to age and others were more gender specific (Mikaere, 2003). Maori women were important in the processes on the marae. This is a perspective current to Maori protocol today and it demonstrates the continuity of tikanga (Mead, 2003). The role of Maori women was and still is imperative to any event held on the marae. While in contemporary times, the belief is that men hold the mana on the marae there are some clear roles for women that indicate the pre-eminence of Maori women in marae protocol.

One specific and crucial example of Maori women and our significance on the marae is that of the karanga. The women's call initiates the formal process, and without this call 
there is no proceeding onto the marae. By calling, the manuhiri onto the marae, the Kaikaranga must acknowledge the dead, the whare tupuna, and identify the purpose of the manuhiri' visit. It is a special role, one that requires knowledge of whakapapa and connections to whenua, a role taught and learnt. No formal hui commences on the marae without the karanga.

Maori women are the first voice (the Kaikaranga) to be heard on the marae. It is a role exclusive to Maori women (Te Awekotuku, 1991). As a Kaikaranga, it is crucial that both worlds, the spiritual and the physical, are connected. The karanga is about our existence and our connection to people, past, present and future. It is about our connection to the whenua and the environment.

It is often inferred that Maori women do not whaikorero on the marae, yet Mihi Kotukutuku of Whanau Apanui is clearly remembered for her stance on the marae, reminding us all of where we come from and why we are all here (Te Awekotuku, 1991). Ngati Porou and Ngati Kahungunu also offer examples of women whose whakapapa endowed them with mana capable of speaking on the marae (Mikaere, 2003). Part of our way as Maori demonstrating our ability to maintain respectful relationships with each other is understanding that often our Maori men will ask Maori women for advice and assistance in regards to their whaikorero and its content (Law Commission - Te Aka Matua O Te Ture, 1999). The assumption that Maori men are superior on the marae is unfounded, and in fact demonstrates how many people are "unschooled in marae protocol" (Law Commission - Te Aka Matua O Te Ture, 1999, p. 13).

A reason given by the Te Arawa people for Maori women not participating in the whaikorero is because the whaikorero was often (based on various iwi kawa) on the marae atea and could become dangerous. Whilst out on the marae atea if a disagreement took place, or the manuhiri came for revenge it was seen best that a male died protecting his iwi, as it was only one life sacrificed, but if a women was to die, future generations would die, having calamitous effects for iwi (Law Commission - Te Aka Matua O Te Ture, 1999). This role and recognition supports the notion of Maori women being tapu and whare tangata, it was a sacred role, a role where Maori women were protected and respected as holding the future.

After the formality of speeches on the paepae, a waiata follows. A complementary waiata that reflects the whaikorero is important to the process. It demonstrates the relationship of balance between Maori men and women (Mead, 2003). The mana of Maori women is further demonstrated in her ability to silence a speaker through the commencement of the waiata (Mikaere, 2003). 
The traditional wealth of a chief and iwi was found in the ability to provide the finest of foods for manuhiri (Mikaere, 2003). It was a gesture of hospitality and generosity (Firth, 1972). The role of women was crucial; they were to uphold the mana of their iwi through hospitality and the provision of food (Heuer, 1969). Failure to do so was the utmost insult. Tikanga and social custom were maintained throughout times of jeopardy as Maori continued to uphold their values of kinship. The role of manaakitanga within traditional and contemporary Maori society is a role in which Maori women are of the essence. Today, we as Maori women continue to uphold this tradition of manaakitanga, in order to uphold the mana of our iwi.

\section{Naming}

There is a connectedness through the whakapapa of Maori to the naming of hapu and marae. There are many references to hapu and marae named after Maori women tupuna (Mahuika, 1975; Mikaere, 1994). This reinforces the significance of Maori women within traditional Maori society. In supporting this claim, Mahuika (1975, p. 344) cites the work of Best, "Occasionally a woman became the founding ancestress of a clan, as in the case of one named Ngati Hinepare". Johnston (2005) also acknowledges that the naming of areas was attributed to both Maori men and women leaders and their connectivity and/or significance to such sites. As Carter (2005) explains, naming and human relationships bind people and their lands. For Maori this interaction is reinforced in our pepeha, where we connect with whanau and geographical landmarks such as land, mountains and rivers. Yet, colonisation has also seen the re-naming or fragmentation of our knowledge and ways of understanding the world (Pihama, 2001). And as a consequence for many Maori, it has created a disconnection to our whenua and whakapapa.

Through traditional forms of communication such as the art of oratory and through reciting whakapapa and waiata, Maori have maintained knowledge which continues to connect some Maori to place and environment (Sharples, 1998). Yet for some unfortunate Maori, colonisation has taken this opportunity from them.

\section{Mana Wahine}

Defining 'mana wahine' is not as simple as it may appear. While wahine can be defined as woman, the definition is more complex than that. ' $\mathrm{Wa}$ ' is time and space and 'hine' is the female essence. As wahine, our journey before life and through life takes us through different times and spaces, and our role as hine is defined by this space and time. As hine we can be mothers, sisters, teachers and grandmothers (Pihama, 2001). 
Mana as described by Manuka Henare (1998) and Rose Pere (1997) is not translatable into one specific term. Mana is generative, multi-dimensional and handed from the spiritual realm. Henare gives a definition of mana "Mana is a quality which cannot be generated for oneself, neither can it be possessed for oneself, rather mana is generated by others and is bestowed upon both individuals and groups" (as cited in Pihama,2001, p. 264)

Pihama (2001) refers to mana wahine as the lived realities of Maori women, defined by Maori culture and underpinned by Maori values and a Maori worldview. Evans (1994) enlightens the meaning of mana wahine through applying self-determination to mana wahine, a process by which Maori women determine their social and cultural future as Maori women.

Matauranga Maori tells us that, "Mana tangata is that possessed by people, mana tane is that possessed by men and mana wahine is by women" (Winitana, 2008, p. 2). This part of the thesis looks at Maori women and their mana. Some examples are given at a national level, but we should not disrespect our own wahine in their roles within whanau, hapu or iwi for inspiring and maintaining mana wahine for the future generations.

\section{Maori Women and Leadership - a Historical Account}

While many recorded accounts of history state that Maori women were not leaders in pre-European times, this is openly contested by such writers as Mahuika (1975) and Rei (1993). Maori women could be Tohunga and often held chiefly roles. Maori women participated in conversations regarding tribal warfare. Maori women were instigators and peacemakers during war. The assumption of leaders being male is often derived from the work of Te Rangikaheke ${ }^{2}$ and Tikitu, who may have taken this stance through the process of colonisation. This assumption is denied by Mahuika (1975) who informs readers that women brought their own special qualities and traits that were important.

Mahuika (1975) details the exclusive role of an ariki being associated with the first born child of a senior line. This aristocratic position was endowed regardless of sex. While Maori women were given the role of ariki, the first born male son was often given the responsibilities of functionality. Mahuika (1975) also documents Maori women as traditionally being political leaders and acknowledges that they were often sought as leaders because of their personal qualities.

Within the kainga, or traditional grounds of Maori livelihood, Maori women were often accorded the same roles as men. Gender was not the deciding factor. Whakapapa was

\footnotetext{
${ }^{2}$ As transcribed in 1849 from the work of Grey New Zealand Maori Manuscript 81 pp. 82 -85.
} 
the significant aspect of organising Maori society (Johnston, K., 2005). Through their whakapapa and knowledge many Maori women were highly ranked experts in a field. Maori women were often associated with the political issues of Maori, and often called on in the decision-making processes that would affect the iwi or hapu (Johnston, K., 2005; Mikaere, 2003). Hine-i-paketia of Ngati Kahungunu and Ngati Te Whatu-i-apiti and Te Rohu of Ngati Tuwharetoa are both fine examples of mana wahine, both having a political voice.

Te Puea, a Maori women from the Waikato offers an example of mana wahine. Te Puea is one of many Maori leaders that represents the holistic Maori approach to leadership. Firth notes that her qualities were personal and endowed to her through birth.

"The achievement of Te Puea, a very remarkable one, was above all to combine in a way which appealed to the people of her tribe traditional Maori cultural values and modern standards of hygiene, sanitation, and economic efficiency. This she was able to do primarily because of her personal qualities" (Firth, 1972, p. 473).

Rei acknowledges this notion in her discussion on Rangatira women. The significance of 'Rangatira women' is defined by Rei (1993) as women who had political power as leaders within the hapu. Te Puea's capability to revitalise the Kingitanga and to develop Ngaruawahia as a self-sufficient community in the 1920's cannot be denied. Here was a Maori woman in a leadership role that was political and beneficial for both her iwi and Maori collectively. Te Puea' leadership is symbolic of Maori women as a leader. She was a Rangatira woman. Te Puea is an example of a woman whose whakapapa determined her status as a Rangatira, yet her actions and achievements which were in the betterment of her people have made her a memorable and recognised leader within the Maori community.

In European terms, a leader is focused on the individual and their success. From a Maori perspective, it is about the whanau, the hapu, the iwi, to which the leader belonged (Firth, 1972). A leader's success, is linked to their mana, a system recognised by Maori as being achieved collectively and bequeathed upon an individual through their achievements (Henare, 1998).

Rei (1993) provides the Ngati Toa chieftainess, Waitohi as another example of a Maori women leader. Under the advice of Waitohi the iwi of Ngati Toa took up residency in the Horowhenua district. Waitohi is further acknowledged and recorded for negotiating on behalf of her brother, Te Rauparaha. Waitohi' Rangatira status was one that her daughter, Rangi Topeora, acquired. Rangi Topeora, like her mother was an influential leader capable of overriding her uncle, Te Rauparaha, in political matters. Rangi Topeora, just as her uncle, 
Te Rauparaha signed the Treaty of Waitangi. Rangi Topeora is recognised as one of the 13 identified Maori women to have signed the Treaty of Waitangi (Mikaere, 2003).

The role of Rangatira was given to wahine, who had appropriate whakapapa lineage and stature within the kainga. Their role was to ensure the well-being and welfare of the kainga. It was often a political role where Maori women were active in the decision-making process, as demonstrated by Waitohi and Te Puea. While Maori women did not normally participate in war, it is noted that in times of need they were present. The following whakatauki clarifies the role of women within the context of war. It also signifies the importance of women to their iwi, "He puta ki te tane, whanau tama ki te wahine" (the battlefield for men, childbirth for women) (Heuer, 1969).

\section{Maori Women and Leadership-Examples in a more Contemporary Time}

While British law and Western belief systems of how Maori should behave and act were being imposed upon Maori, Maori women were declaring a stance for equality and a right to participation. This is evident through the activities of Maori women in the Women's Christian Temperance Union and the Suffrage movement. The Suffrage movement was a world first, where both European and Maori women won the right to vote for members of the New Zealand House of Representatives. The efforts of Mere Mangakahia were recognised in 1897 when Maori women won the right to both vote and stand for the Maori parliament (Rei, 1993). Maori women knew that in order to create social change within New Zealand, they needed to be active participants. The Maori Women's Welfare League currently has a claim lodged with the Waitangi Tribunal. The 'mana wahine claim' is founded on the lack of recognition for Maori women's rights. More recently, the Treaty of Waitangi Fisheries Commission raised concerns at the lack of Maori women representatives appointed to the Commission (Mikaere, 2003). This has triggered a reaction to the fact that there were very few appointments of Maori women to other Crown boards and agencies.

Many Maori women have continued to demonstrate their mana as wahine and some examples are now provided. It is not intended that this be exhaustive, merely an overview of their achievements and a recognition of Maori women who have maintained our mana as Maori women.

\section{Te Kotahitanga}

On $13^{\text {th }}$ June 1892, Maori established the Maori Parliament with the objective to have the Treaty of Waitangi enforced to protect the depleting ownership of Maori land. Maori Parliament became a forum where both Maori women and men had the right to speak (Rei, 1993). At the official opening ceremony, Maori women demonstrated their mana through 
participation in the haka (Rei, 1993). Today the perspective within society is that the haka is only performed by men.

By 1893 membership of the Maori Parliament had grown to 21,900. This same year Meri Mangakahia, the daughter of Hana Tera and Te Tai, a high-ranking man of Te Rarawa, became an icon for Maori women. Meri initiated the right of Maori women to vote. Meri' justification being that some Maori women were knowledgeable about the land, and that some were widowed, had no father or brothers to speak on their behalf. The initial motion was deferred on the grounds that the constitution had been finalised. It was four years after the initial motion that Meri Mangakahia's proposal was endorsed. Maori women won the right to vote and stand as members of the Maori Parliament (Rei, 1993). Meri Mangakahia's action exemplifies the mana of Maori women in earlier times through her political stance and ability to gain equality for Maori women.

\section{The Electoral Act}

In 1891 New Zealand women collectively (both Maori and European) requested and fought for the right to vote. This gesture was denied to all women by the hegemonic society which plagued the minds of both Western and at this time, our Maori men. However, late in 1892 support was noted through the words of Mr Eparaima Te Mutu Kapa of Te Aupouri. In a newspaper interview Eparaima is quoted as saying, "Women's intelligence made it an injustice to deny them the vote" (as cited in Rei, 1993, p. 29).

On $8^{\text {th }}$ September 1893 , the Suffrage Bill was passed. This battle was a victory not just for Maori women, but for women collectively in New Zealand. Women were given the right to vote. Maori women who owned freehold land could now vote on either the general roll or the Maori roll. This victorious year saw an estimated 4,000 Maori women vote (Rei, 1993). Yet for many Maori women, this day came too late, with much of the Maori land previously owned by Maori women now in the hands of their husbands.

\section{Maori Women's Committees}

While hegemony plagued New Zealand society, it did not stop Maori women from forming collectives that gave them the freedom to discuss matters of mutual concern. These committees were often formed on a national level.

Early in January 1895 at Te Hauke, a hui was held that soon caught the attention of the European society with articles being written in the newspapers. Maori women had called for discussions to take place regarding land matters and the equality of gender within the forum of the Maori Parliament (Coney, 1993). Nga Komiti Wahine was established by Maori women in 1897 to discuss matters such as health, education and land issues of importance 
to Maori (Rei, 1993). This forum enabled Maori women to freely discuss matters of national importance, ordinarily prohibited by European society. Prostitution, land rights and other significant matters such as alcoholism were also topics of discussion (Rei, 1993).

Due to the increased concern for health, education and other matters, there was a push for another forum for Maori women to engage in. Maori women needed a place where their voices were heard. In 1951, the Maori Women's Welfare League commenced (Coney, 1993). The Maori Women's Christian Temperance Union was well established by 1897. This organisation arose out of the existing Women's Christian Temperance Union.

\section{Maori Women's Welfare League}

The origins of the Maori Women's Welfare League stemmed from a government initiative under the Maori Social and Economic Advancement Act 1945 (Coney, 1993). The primary objective was health, education and the overall welfare of Maori. In September 1951, the Maori Women's Welfare League was formed as an Incorporated Society (Evans, 1994; Mikaere, 2003). The league was a response to the urban migration of Maori. Under the recommendation of Rangi Royal, Maori welfare officers set up 165 branches.

The inception of the Maori Women's Welfare league is defined by Rumatiki Wright, a Maori Welfare officer of the Department of Maori Affairs. "The League is sponsored by the Department of Maori Affairs not with the object of segregation, but to see if we can look after ourselves" (as cited in Coney, 1993, p. 132). This very matter was discussed by Maori women as a concern that government might control the direction of the league in a hui prior to the establishment of the Maori Women's Welfare League in 1950 (Coney, 1993).

In its 1954 spring edition, the magazine Te Ao Hou recognised that the biggest job of the Maori Women's Welfare League was to foster deeper and wider understandings and relationships between Maori and European people. It also maintained that the task of the League was to encourage Maori to take their place in both the Maori and European worlds, with confidence and having full rights under the Treaty of Waitangi (Strum, 1954). Today this focus remains important to the Maori Women's Welfare League. With the motto, "Tatau Tatau", (Let us be united), the Maori Women's Welfare League continue today with the same kaupapa (Coney, 1993).

The Maori Women's Welfare League has developed and provided a wealth of Maori women leaders, such as Whina Cooper, Mira Szaszy and Aroha Reriti-Crofts who have helped both maintain and reclaim mana for Maori wahine (Coney, 1993). 


\section{The Kohanga Movement}

Kohanga derives its name from 'whare kohanga', the place where Maori women traditionally gave birth, a tapu place, a nesting house (Jenkins \& Mountain Harte, 2011; Mikaere, 2003). The first kohanga reo was established in 1982 by the Department of Maori Affairs after Maori raised concerns over the survival of Te reo. The delivery of education incorporated Maori ways of learning, kuia and kaumatua were involved and Maori pedagogies were part of the curriculum (Bishop, 1998; Hohepa, 1993). Bishop recognises Te Kohanga reo as, "an education that maintained their own lifestyles, language and culture while also enhancing life chances, access to power and equality of opportunity" (1998, p. 5). What we see in this statement is that Te kohanga reo is a transformative education strategy that demonstrates self-determination (Smith G. , 1997).

Te Kohanga, Whare wananga and Kura kaupapa are all examples of Maori educational initiatives that have seen Maori challenge the New Zealand education system. Maori women, such as, Iritana Tawhiwhirangi were very much involved in the Kohanga movement.

\section{Summary}

In reviewing this chapter, it has been important that the narrative demonstrates the role of Maori women in both worlds - the metaphysical and the mortal. Re-examining the past of Maori women and telling our story as Maori is crucial to the use of a kaupapa Maori methodology. It is a challenge to hegemonic discourse, and an attempt to regain our knowledge in the light of resistance.

This chapter celebrates the mana which we as Maori women were gifted through our metaphysical worldview. Maori women were respected as the mothers of the future, as leaders, and as integral components to the metaphysical world and the natural world and to mortality. It is through our whakapapa and matauranga Maori that these connections are made (Mikaere, 2003).

Matauranga Maori informs us that our relationship with the whenua is part of our identity. These three key elements are connected through our whakapapa, and will later in the thesis be defined through an educational lens. It is hoped this chapter has given the reader an insight into the relevance of our epistemological knowledge and the position of Maori women.

It is suggested that gender specific superiority was a colonising effect that impacted heavily on Maori women. (Johnston, K. , 2005). Women collectively in New Zealand were marginalised by this idealism, yet Maori women were further disparaged through racism. 
Fortunately, some Maori women certainly have maintained roles or status and stature within their whanau, hapu and iwi not because of their gender, but because of their whakapapa an endowed system of mana and continued to uphold our role as mana wahine (Pihama, 2001).

In the next chapter a discussion about how Maori women were marginalised through colonialism and imperialism will take place. Legislation, religion and education will be analysed to define how Maori women and their lives were effected. 


\section{Chapter 4: Examining the Marginalisation of Maori Women}

\section{Introduction}

Marginalisation is a term used to define people that have been disadvantaged or pushed to the exterior of society. Within the context of this thesis, I am talking about Maori women being disadvantaged and pushed to the outside of New Zealand society.

Marginalisation requires a set of people to be 'outsiders' or 'the other'. They are not the same, one group is superior, and the lesser group are the 'others' or 'outsiders' (Foucault, 1964). Marginalisation calls for a group to be seen as sub-standard, second rate and in some instances invisible (Staszak, 2008).

In this chapter I demonstrate how colonialism and imperialism pushed Maori women, to the outer fringe of New Zealand society. Collectively Maori were marginalised, but Maori women we were further marginalised because of our gender. The ability to distinguish people through gender, class and race was crucial to colonialism and imperialism (Seuffert, 2005). It permitted domination and power (Staszak, 2008), two mechanisms which enabled Maori women to be marginalised.

In the previous chapter, I discussed the role of Maori women, prior to the arrival of the colonists. Maori women were significant as leaders, in the metaphysical realm and the human world, we were significant in the naming of places and hapu, and were significant as contributors to the daily lives of whanau, hapu and iwi. Colonisation distorted the contribution of Maori women to society in favour of European ways and beliefs (Johnston, K., 2005).

In times prior to colonisation the land was never in personal names, it was a right gifted through whakapapa, a right bestowed upon Maori as whanau, hapu and iwi (Johnston, K., 2005). Land became a right, not through title, but through the maintenance of ahi kaa (keeping the fires burning) and the connection to the land, this was our tikanga.

The coloniser' gained titles through patriarchal systems of hierarchy and control. Many Maori women's children were no longer gifted their lands through tikanga. Legislation prohibited it due to traditional marriages and births not being recognised under the colonisers' law. Consequently, many Maori women lost their identity, their sense of belonging and their connection to their turangawaewae, or place to stand (Pihama, 2001).

Having been marginalised many Maori women became 'invisible' (Mikaere, 2003). We lost our land, our connection to the whenua, our ability to culturally identify. With amendments to legislation, the identity of Maori women continued to be undermined, we became the property of our husbands (Mikaere, 1994). Legislation saw Maori women 
isolated and absent from decision-making processes. As a result many Maori women were 'dehumanised' and 'invisible'.

Our knowledge base, 'matauranga Maori', was misinterpreted and redefined by the missionaries and by European worldviews (Mikaere, 2003; Pihama, 2001). Maori women, who once had status because of their whakapapa and gifted qualities, were undermined. Maori women were made lesser, and were marginalised, a system which Freire (1995) calls “dehumanising”. This system saw European culture as superior, Maori men as second class and Maori women as inferior (Pihama, 2001).

\section{What Happened to Us?}

Johnston (1998) asserts that in order to be assimilated three components were required in New Zealand. There was a need to form one race, one law, and the civilising of Maori to abide by European norms. It was a systematic approach brought about by racial, sexist and cultural stratification and implemented through various colonising structures. Legislation, education and religion worked hard to silence Maori women. The Eurocentric beliefs that existed in colonial times continue to have consequences for Maori women today (Pihama, 2001).

Whilst the overriding authority of English law and its application to Maori women impacted heavily upon the mana of Maori women in New Zealand society (Law Commission - Te Aka Matua O Te Ture, 1999), Maori women have continued to exercise mana wahine under Maori lore, on the marae. Maori women are the initiator of all hui. Maori women (Kaikaranga) must firstly call the people (karanga) before any matter can be dealt with. The karanga is a form of communication, a form of whaikorero, that connects the spiritual and the physical world (Mikaere, 2003). It is a role that continues to be exclusive to Maori women and is vital to any powhiri as it is calls for knowledge of whakapapa from both worlds and the blending of these worlds together.

Maori women and their ability to speak on the marae were also affected by the European concept of the role of women in society. Today there continues to be an assumption that it is the exclusive role of men to speak on the marae, yet writers such as Mahuika (2003) and Salmond (2004) both provide evidence of women who had such responsibilities. What it symbolises is a process of patriarchal power imposed upon society that continues to misrepresent the role of Maori women (Smith, L., 1993).

Maori women who married under European law became the legal property of their husbands (Rei, 1993). The customary practice of marriage under Maori lore was no longer recognised. Maori women were alienated from traditional processes of familiarity in favour 
of Christian belief systems (Mikaere, 2003). Colonisation has affected our past and our present and continues to be a part of our future. Our lands have been taken, our culture suppressed, and our livelihoods affected (Mikaere, 1994).

The colonial education system in New Zealand failed Maori children. As Maori, we were alienated from our way of thinking, our beliefs and our culture (Leoni, 2009). Traditional education in New Zealand was based on the Western ideology that a European way of life was superior, and that European knowledge, way of life, spirituality and worldview was superior (Leoni, 2009; Mikaere, 2003). At school, legislation required that Maori children refrain from speaking Te reo and participate in the coloniser's religious instruction. This legislation impacted upon the Maori worldview. Schools as instruments to colonise remain a site of struggle for Maori. Today, low outcomes for Maori continue to be of concern, yet the curriculum continues to be foreign to Maori (Leoni, 2009). Today many Maori women are attempting to resist the influences of colonisation (Smith, L., 1993).

\section{What is Marginalisation?}

Smith (2006) reminds us as Maori women that patriarchy, colonisation, sexism and racism are interrelated. The objective was to exclude Maori women or as Mikaere (2003) asserts, to make us 'invisible' through making us non-existent or lesser. This is marginalisation; it is the exclusion or the pushing to the outer, causing individuals or a group to become less significant than that of the dominant group. This is probably best defined in the following manner, "Marginalisation occurs when a group of people are pushed to the periphery of a society" (Ormond, et al., 2006, p. 181). Today marginalisation continues to affect Maori women from within the European world and the Maori world, or as McIntosh states, "We can take as a given that many Maori live lives that are at the margins of both 'mainstream' as well as Maori society”' (2006, p. 47).

Freire (1995) likens the process of marginalisation to what he terms “dehumanization", a system of 'oppression' that exerts power over a group in order to make them feel less human. Foucault (1964) discusses the idea of marginalisation through the term "othering", a process where a dominant group pushes the less dominant group to the outside boundaries of society. Othering divides people into two groups; one that is valued and classified as normal, the other is devalued. Maori were devalued by historical researchers who recorded Maori as, savage, inferior and barbaric (Best, 1934), yet the effect of othering upon Maori women is even deeper devaluing because of the myths of superiority practised by those responsible for the marginalising process . Historical researchers valued Western civilisation and dominated their existence over the minority group (Maori civilisation). As a 
consequence of this dominance, the process of assimilating Maori, and in particular to this thesis, Maori women with the intent of exterminating our cultural way of being commenced in New Zealand (Staszak, 2008).

\section{Colonisation and the Effect it has had on Maori Women}

Ka hura au ka takahia mai

Ka kuare noa nga owatitanga

E kore au e ngoikore noa

Ka whawhai tonu ake ake ake

(Tuini Ngawai)

As demonstrated in the previous chapter Maori women were significant contributors to the Maori worldview. We were respected as having a role within both the metaphysical world and the human world. This chapter talks about how Maori women were marginalised and made insignificant through the implementation of colonialism and imperialism. Colonisation and imperialism impacted upon the traditional concept of mana wahine (Johnston, K., 2005). This is not to deter from the fact that Maori men were marginalised. They were racially - but as Maori women we were further affected by sexism (Mikaere, 2003).

Colonisation is a process where one nation assumes power or control over another nation. Once the Treaty was signed, the British Crown worked hard to rule New Zealand and legislation is used in this thesis to demonstrate the impact in which British sovereignty had on Maori women. It wasn't until 1852 that legislation was passed to create New Zealand as a British entity, yet British law and legislation was already well established by this time in New Zealand.

Colonialism in New Zealand was rapid. Within 16 years of signing the Treaty of Waitangi, Maori were outnumbered; we were the minority group in a land that was once exclusively ours. Our minority status and the increase in British settlers, soon hastened the need for legislation that empowered the British settler. Unfortunately for Maori what was signed in the Treaty of Waitangi was to be demoralised (Johnston, K., 2005). Our taonga, inclusive of our ways of self-governance and lore (tikanga) was undermined in favour of the newly arriving civilisation.

Legislation was a critical component of colonisation and is discussed in this chapter. The education and religious impact upon Maori women will be discussed later in this chapter as an effect of imperialism. 


\section{Tikanga and Maori Lore - our System of Law (Lore)}

Tikanga underpins our being in a cultural sense, it is unique to Maori. Tikanga is derived from the adjective 'tika' it is about how and why we as Maori do things; it is informed by matauranga Maori. Tikanga are our rules, they guide how and what we do. Central to the concept of tikanga are the values that underpin it. The position of tikanga within Maori society establishes how as a people, we operate. Values such as aroha, whanaungatanga, mana, utu, kaitiakitanga, tapu, noa, wairua and mana tupuna underpin tikanga (Mead, 2003). While each iwi, hapu and whanau may implement them in a different manner (kawa - the practice of how they are undertaken), each value remains evident throughout Maori culture (Boast, Erueti, McPhail, \& Smith, 2001).

From a Western viewpoint, tikanga was seen as male-orientated (Mikaere, 1994). This is an incorrect statement founded on the historical researcher's bias and misinterpretation. Tikanga is not defined on the basis of gender (Johnston, K., 2005); it is based on matauranga Maori, our epistemology as Maori. In accordance with tikanga, the Maori world was tribally based, with whakapapa identifying membership, responsibility and rights. Tikanga required the acknowledgement of both mana wahine and mana tane (Johnston, K., 2005). Mikaere (1994) calls for both tane and wahine to actively utilise and implement tikanga within their whanau as a way of understanding that tikanga is not gender based and does not exploit Maori women. Tikanga does not exist as a tool to impose power and authority, it is not suppressive.

Tikanga provides a guideline for living. Tikanga is about balance and collective living. Tikanga is bequeathed to us as people through our ancestors. Tikanga is both flexible and practical, designed to enable us to live in harmony with one another and our environment. The flexibility of tikanga is determined by circumstance and location (Johnston, K., 2005), yet the fundamentals of tikanga do not change. Tikanga is the customs, practices and protocols which inform a Maori way of life. This way of life was "our law" (Ward, 1983, p. 2). Jackson (1995) notes that Maori did not have law; instead what we have is lore. A system of law that is based on tikanga. It is derived from our geographical relationship with the land (Durie, 1998; Seuffert, 2005) and informed our way of life, and how we conducted ourselves.

In considering tikanga, another important aspect is the maintenance of ahi kaa. For many Maori we can whakapapa to many iwi and hapu, but it is not necessarily our place to talk on their behalf. The people who have maintained ahi kaa have 'kept the fires burning' they have lived on the land, know the land and have an affinity with the land. They are the 
caregivers (kaitiaki) for us who return later. Tikanga states that they (people who have maintained ahi kaa) have the right of decision making over the land and political matters that affect the land and its people (Mead, 2003).

\section{How Legislation Marginalised Maori Women}

The 1700's was a pivotal time in British history where gender and the differences between men and women became 'naturalised' (Laqueur, 1990). The role of men and women had been socially constructed. British society had rendered their perception of what women were - their capabilities and their roles (Laqueur, 1990). By the 1800's law began to reflect the new perception and women became excluded from the rights of equality because of their gender (Smart, 1992). The adoption of British law in New Zealand saw the British perception of women being imposed upon Maori women and making us invisible.

Today this history has caused Maori women to call for legislation that is respectful to women. However, the assumption that neutralising (gender free) the terminology used in legislation would benefit women is incorrect (Smart, 1992). This assumption does not remove societal perceptions, nor does it remove the discrimination and the positioning of women. Because legislation is embedded in society, changing gender discrimination can only happen through social change (Smart, 1992). In order to create social change, education becomes an important tool. Without re-educating and social change the neutralising of legislation is like a sticky plaster, only covering the issue not fixing the problem.

Anthropologists have established that Maori, like other Indigenous cultures certainly practiced a law, or lore within their society. Slowly, with the introduction of British law, Maori traditional practices of law (lore) were reduced. Maori, and in particular Maori women, were alienated from their rights as Indigenous people.

Interestingly enough, Jackson (1995) also acknowledges that one law for all is not necessarily the answer. Law does not factor in culture, and one law in New Zealand has already demonstrated its suppressive nature for Maori. Not only has one law within New Zealand meant that our lore as Maori is not acknowledged, but it also created a monocultural way of identifying people in New Zealand. This in turn effected our Indigenous identity as Maori (Jackson, 1995; Seuffert, 2005).

Maori were not supportive of British law. Samuel Marsden states that before 1820 Maori were resistant to British law stating that, "the chiefs would hesitate before they placed their country under the power and government of a foreign nation" (as cited by Ward, 1983, p. 17). 
The arguable intention of the British Crown was not annihilation of the Indigenous culture and people, but that Maori would continue to govern (Frame, 1981), under their systems of law; customary lore. Frame (1981) cites Stanley Diamond in noting that, "the relationship between custom and law is, basically, one of contradiction, not continuity". British law and Maori custom did not align and worked at opposite spectrums, with legislation ignoring Maori customary lore. This is a sad statement, but one which is made real through the process of colonisation within New Zealand. The health and well-being of Maori was affected by legislation (Parker, 2005).

British legislation marginalised us, not only through defining us, but also through excluding us (Mikaere, 2003). And through the amendments, the legislation went further and re-defined us. This not only affected our relationship with the British who settled here, but as Maori, we started to define ourselves through the legislation (Mikaere, 2003). The legislation removed our ability as Maori women to make decisions publicly and politically (Johnston, K., 2005).

Much of the legislation in $19^{\text {th }}$ century New Zealand attempted to define what being Maori meant. The 1867 Maori Representation Act defined Maori as, “A male aboriginal native inhabitant of New Zealand", as Maori women, we were invisible. The consequences of early legislation continues to be just as relevant today as it was in colonial times, as the marginalising effects remain (Wilson, 1993).

The 1904 Education Act defined Maori as being, "any person of Aboriginal race of New Zealand, and every person whose parents was deemed to be an active member of such race. But no half caste shall be deemed to be Maori within the interpretation of this Act." The Act further clarifies its sexist position of who is Maori by adding to the definition, "unless he has been living as a member of some tribe or community", again Maori women had no identity within the legislation; we were English, we weren't Maori, we were nonexistent.

Each of these Acts fail to acknowledge Maori women as having rights, in fact what they do is eliminate us, Maori women were invisible, we simply weren't there (Staszak, 2008). The inability for legislation to acknowledge Maori women in their definition of what a Maori is, is sexist. Binney (2006) describes the impact that defining Maori in legislation had upon Maori as dire to our cultural way of life. Legislation alienated Maori from their lands and was subsequently causal to the breakdown of whanau, hapu and iwi structures, impacting upon the social, economic and political activities of Maori (Johnston, K., 2005; Mikaere, 1994). 


\section{The Treaty of Waitangi}

"The relationship between Maori and Pakeha under the Treaty as a partnership after 150 years of brutal colonizing tactics perpetuated by the Crown on Maori, failed to produce a level playing field for the two partners" (Seuffert, 2005, p. 8).

In fact, what signing the Treaty did for Maori was to create an unfair playing field, where the Crown imposed their worldview upon us as Maori.

On $6^{\text {th }}$ February 1840 at Waitangi, a treaty between Maori and the British was signed. This treaty was to be known as the Treaty of Waitangi, a document written in English and then translated into Te reo Maori. The English version had 39 signatories and the Maori version between 530 and 540 signatories (Whiu, 2001). Yet the official document was to be the English version. In 1877 the courts concluded that the Treaty of Waitangi was a "simple nullity". Later, in 1941, the Privy Council refused to recognise the Treaty, stating that it was unenforceable in New Zealand unless it was passed in legislation (Seuffert, 2005). In 1975, after much protest, the Crown passed the Treaty of Waitangi Act. The relationship of Maori women in these protests for social justice is probably best described by Kelsey in the following quote,

"Maori grievances over the theft of land, suppression of culture, dishonouring of the Treaty of Waitangi, and denial of economic and political self-determination had become the focus of high-profile protests, frequently led by powerful and articulate Maori women" (1993, p. 233).

What the Treaty of Waitangi Act 1975 permitted was the establishment of the Waitangi Tribunal, able to hear claims of injustice from 1975. This was seen as ludicrous and was protested against, as the historical injustices were not being addressed. In 1985 the Treaty of Waitangi Amendment Act was passed, enabling cases to be heard dating back to 1840 (McIntosh, 2003; Seuffert, 2005). Today New Zealand is in the process of redressing the historical injustices that the Crown impelled upon Maori (Seuffert, 2005).

At the time of the Treaty of Waitangi being signed Maori women were very much involved in the political and social events of iwi. The mana Maori women had pre-colonial times is clearly verified in the ability of women to sign the Treaty (Rei, 1993). In earlier stories of the signing of the Treaty, the number of Maori women who signed was said to be five and six, yet to date, 13 women have been identified (Mikaere, 2003). The gender-neutral process of naming people in traditional Maori times remains a challenge in defining the 
actual number of women who signed the Treaty. While there is evidence of Maori women being declined the right to sign the Treaty (Mikaere, 2003; Seuffert, 2005), this is often associated with the European perspective of women as having no rights. In fact, Major Bunbury, a military officer of Britain, tasked with collecting signatures for the Treaty of Waitangi, refused to allow Maori women to sign the Treaty of Waitangi (Law Commission - Te Aka Matua O Te Ture, 1999).

Article 3 of the Treaty of Waitangi has had a catastrophic effect on Maori women. While this article promised Maori women all the rights and privileges of British subjects, it did not state that their rights as mana wahine would be damaged. What we see in the history of New Zealand is certainly that all the rights and privileges of British subjects were to be legislatively imposed on us as Maori women. Maori women were undermined through giving us the same rights and privileges of British women.

Legislation and the developing societal ways influenced by the British through education and religion was to see the role of Maori women follow that of their British counterparts. Maori women were expected to become subservient and invisible (Law Commission - Te Aka Matua O Te Ture, 1999). Maori women were to be assimilated and become like British women.

\section{New Zealand Settlements Act and the Suppression of Rebellion Act 1863}

These Acts enabled the Crown to confiscate lands if Maori fought, harboured and/or participated in wars against the Crown (Kelsey, 1984). For many Maori this saw them being forcibly removed from their whenua. For many Maori women and their children this had severe consequences, with many of them isolated from the whanau, hapu and iwi. Their husbands and fathers, who were fighting the Crown to prevent such action, were separated from their whanau and their whenua. The men were imprisoned, without a right of appeal. Johnston (2005) uses the work of the Waitangi Tribunal report relating to Taranaki when she says that the action of the Crown was deliberate and intentional. The Crown saw a solution in taking land from Maori in order to meet the needs of settling British citizens.

These two Acts collectively saw the confiscation of 3 million acres of Maori land and the imprisonment of Maori (Kelsey, 1984). This has been causal to dislocating many Maori, creating constraints on their ability to identify themselves, to have a sense of belonging and an understanding of matauranga Maori through the prohibition of lived experiences. 


\section{The Native Land Act and its Amendments}

The Native land Act in 1862 provided the facilitation and implementation of the Native Land Court (Law Commission - Te Aka Matua O Te Ture, 1999). The Native Land Court was established and consisted exclusively of European men (Johnston, K., 2005). The Native Land Act was pivotal in creating individual titles for Maori customary land. Individual titles to land was unfamiliar to Maori, as pre-colonial contact, Maori land never had titles or ownership (Johnston K., 2005). The effect of titles over Maori customary land undermined and disassociated many Maori from their customary land. This process was swift and by 1900 Maori held less than $10 \%$ of their lands under customary law (Johnston, K., 2005).

Until the Act was amended in 1873, Maori women were recognised by the Native Land Court as having property rights (Binney, 2006). According to Rei (1993), in the attempt to rectify the wrong-doings of land loss, Maori women tried to secure their lands through the Native Land Court. Women like Maata Te Taiwatea of Ngati Awa, devoted her time to sorting the return of Maori land.

However, Binney (2006) paints a different picture, whereby Maori women actively assisted their European husbands in gaining ownership of Maori land. Binney tells of cases of Maori women married to European men going to the Native Land Court, subdividing blocks and transferring them to their husbands. The position of such Acts created other complex issues relating to land tenure, such as retrieval or inheritance. As a consequence, a Maori woman who left her husband, or vice versa, could not regain her land. It was lost forever. It is suggested that European men were marrying Maori women in order to acquire land (Binney, 2006).

The Native Land Act changed in 1873, and caused greater disparity and isolation from lands. All transactions regarding Maori women in the Native Land Court now needed to be signed by their husbands, to confirm approval of her actions (Binney, 2006). Yet the newly acquired European law enabled a European husband to sell lands, without the consent of his wife, even if she was the original owner; the title was now his under marriage and law (Coney, 1993).

Today the corollary of the Native Land Act and European law in alienating Maori (Law Commission - Te Aka Matua O Te Ture, 1999) from their traditional land has had a profound effect, contributing to urbanisation. Consideration of Maori and their connectedness to the land was never factored (Boast et al., 2001). Horiana Tiakitai of Ngati 
Kahungunu puts the land sales in context, "the greatest disaster to touch us" (as cited by Coney, 1993, p. 285).

In pre-European times this colonised process of male domination over land did not exist in the Maori world (Law Commission - Te Aka Matua O Te Ture, 1999). Native marriages were no longer recognised, and children born of them were classed as illegitimate, forfeiting their rights to succession under legislation.

Under the Native Land Court, adoption (or as Maori knew them - whangai) was to be recorded under an arrangement by order, so that any lands and their succession could potentially be acknowledged. This was soon concreted into legislation, as all the order at that time did was to acknowledge the relationship; not give a right to succession. The Native Land amendment Act 1909 gave legal status to adopted children, thereby allowing the lands to be rightfully succeeded to (Mikaere, 1994).

\section{The Matrimonial Causes Act 1857}

The Matrimonial Causes Act of 1857 saw the Maori custom of marriage as invalid (Law Commission - Te Aka Matua O Te Ture, 1999). Traditionally, from within Te Ao Maori (the Maori worldview), Maori women were not the 'property' of their husband, nor did marriage mean Maori women gave up her whanau, whakapapa or whenua (Mikaere, 1994). The effects of the Matrimonial Causes Act were not too dissimilar to that of Native Lands Act. If a Maori woman married under the Matrimonial Causes Act, her land rights under the Native Land Court became the property of her husband (Rei, 1993). The intended or unintended consequence of this could be, and was, the loss of Maori freehold land. This is a clear display of discrimination and inequality in which British law impacted profoundly on Maori women. Issues of land alienation affected not only Maori women, but the hapu as a collective (Law Commission - Te Aka Matua O Te Ture, 1999). Lands owned by Maori women instantly became the property of the husband (Mikaere, 1994).

Another direct effect of the Matrimonial Causes Act concerned the legitimacy of children. A child born outside of wedlock in the European system of law was not recognised as having rights to inheritance (Law Commission - Te Aka Matua O Te Ture, 1999). In terms of a bicultural marriage under Maori customary lore (a process not recognised by the legislation within the developing society of Aotearoa) the children were deemed illegitimate and unable to inherit from their European parent. In accordance with English common law, women and children were chattels and their identity was undermined through legislation. 


\section{The 1847 Education Ordinance and Native Schools Act}

This Act saw the development of formal European education within New Zealand. While missionary schools already existed, they were now recognised legislatively. Pihama reminds us of George Grey’s expectations for education;

"All schools which shall receive any portion of the Government grant, shall be conducted as heretofore upon the principle of religious education; industrial training and instruction in the English language, forming a necessary part of the system in such schools" (2001, p. 212).

The Act further stated that religious head figures shall manage schools and that these persons shall have control over teachers. Such religious figures were male only, thereby eliminating women from having any ability to manage and supervise the education of children (Pihama, 2001).

It is here our Maori children began lessons in thinking that the Maori way of life was 'inferior' and they soon learnt European ways of life and understanding the world (Leoni, 2009).

\section{The 1867 Native Schools Act}

The Native Schools Act enabled primary schools to be established under the control of the Native Department. Maori were expected to donate land and contribute to the buildings and teaching salary for the development of a primary school in their community.

Sections 5 and 6 of 1867 Native Schools Act states that if "male adult natives" chose to call a meeting and vote for the area to be financially assisted by Maori to develop a school then that would take place. The legislation was gendered, and alienated Maori women from being part of the decision-making (Pihama, 2001). Maori women were 'invisible' to the process (Mikaere, 2003). Changes to this Act took place in 1880 under the Native Schools Code, to now specify that "at least ten Maori" shall form the decision-making and that if it was agreed to, Maori would provide two acres of land and contribute financially to the Government for expenditure related to the school (Pihama, 2001).

While the Act was now gender free, the colonial ideologies of expected gender roles continued (Pihama, 2001). The Native Schools Act enabled the government to control the education of Maori (Leoni, 2009). Under this Act the missionary schools were replaced with the Native schools. The expectation of these schools was to be a "beneficial influence on the Natives" with the desire that the teacher and school master demonstrate to Maori how they could possibly live a 'useful and blameless life' (Pihama, 2001). 


\section{The Tohunga Suppression Act 1907}

New Zealand history records that upon the arrival of Europeans, Maori were healthy. Yet along with the settlement of the Europeans came diseases that were unfamiliar to Maori. The Maori Tohunga were unable to cure these diseases and were soon ridiculed and their abilities questioned (Smith \& Simon, 2001). The Act discredits the role of the Tohunga and implies that the Tohunga was a fallacy. The Act states;

"Every person who gathers Maoris around him by practicing on their superstition or credulity, or who misleads or attempts to mislead any Maori by professing or pretending to possess supernatural powers in the treatment or cure of any disease, or in the foretelling of future events, or otherwise"(The Tohunga Suppression Act,1907). This Act could see Tohunga fined or imprisoned under legislation.

Through this Act, the role of Tohunga, responsible for the traditional spiritual and educational practices of Maori was outlawed (Kelsey, 1984). The outlawing of the Tohunga was crucial to the ability of the teachers under the Education Act to assist with the health care of Maori (Smith \& Simon, 2001).

The Tohunga Suppression Act and the 1904 Midwives Registration Act prevented Maori from practising their traditional ways of birth. The Tohunga played an essential role in traditional birthing practices, a role that included waiata, reciting whakapapa and in tohi (similar to baptism).

Another aspect of how the Tohunga Suppression Act effected the Maori cultural practices was the inability for Maori to engage in the activity of 'Moko'. Moko or Ta moko is similar to a tattoo, but differs in the fact that it is etched into the skin, not on the skin. For Maori, moko is a form of communication that gives your identity, it holds your whakapapa and your role within your whanau, hapu and iwi. The 'Tohunga ta moko', (person responsible for undertaking ta moko) could be either male or female was outlawed and prohibited from undertaking this ritual (King, 1973). Maori women are well recorded in history for their moko kauwae (chin moko).

Yet even prior to the introduction of the Tohunga Suppression Act, Moko as a Maori art form of communication and identity had been effected through imperialism. By 1865, New Zealand was in the midst of social reconstruction and the worldviews of new settlers saw the moko unfavourably (Gallagher, 2003). In fact what was said by Yates regarding the practice of ta moko was; 
"that in all mission stations tattooing has been forbidden, and that it is generally understood that any person coming to live at a mission station must no longer submit himself to 'such a savage and debasing performance" (as cited by Gallagher, 2003. p. 43).

The Tohunga Suppression Act 1907 remained active until it was repealed in 1962. By this time many Maori believed that the expression of wairua-based beliefs was dangerous and inappropriate in the newly formed New Zealand society. This aspect of colonisation contributed significantly to the loss of access to traditional wairua-based knowledge. Natural medicines and the understanding of the Maori world-view were undermined and outlawed by this legislation (Smith \& Simon, 2001). Today we see a resurgence of Maori cultural activities, such as ta moko (Gallagher, 2003).

\section{How Imperialism Marginalised Maori Women}

Imperialism is political and economic domination (just like colonisation), but imperialism does not require the establishing control or the colonising of a country (Said, 1994). Imperialism is a term used to distinguish itself from colonialism. Often the terms are inferred as the same (Clayton, 1996). Imperialism was evident in New Zealand prior to colonisation. For the purpose of clarity, imperialism is used in this thesis, acknowledging that religion and education alienated Maori women prior to New Zealand being colonised. The missionaries had established western forms of education and religion in New Zealand before the British formed New Zealand as a colony.

Not long after the arrival of James Cook in 1769, New Zealand soon saw the arrival of sealers, whalers and traders to New Zealand. Prior to the establishment of British sovereignty in New Zealand the traders and the missionaries were exercising political and economic domination and power over Maori (Said, 1994).

An examination of religion and education from an imperialistic lens are investigated to demonstrate how Maori women were marginalised prior to British rule in New Zealand. It is important to also acknowledge that upon British sovereignty over New Zealand, religion and education continued to be assimilative, but became a colonising tool through the implementation of legislation.

\section{Christianity and Western Concepts}

Maori initially welcomed the missionaries (Mikaere, 2003). Maori could certainly see the advantage of befriending the newly arrived people, they had tools and other resources that were of interest to Maori. 
Unfortunately, at least with regards to the Maori epistemological viewpoint, the missionaries brought with them their religion, a religion that saw Maori women created from man (Mikaere, 2003), a system that saw men descend from the heavens and women derived from the land. Our story of creation was re-interpreted (Best, 1934); men were now deemed divine beings. Pihama defines this status in the following quote from Helene Connor, "Unto woman he said, I will greatly multiply thy sorrow and thy desire shall be to thy husband and he shall rule over thee" (2001, p. 158). Through religion, Maori women were seen as subservient to man. The mentality of man being superior is evident throughout Western religious literature such as the $\mathrm{Bible}^{3}$, "But I want to understand that the head of every man is Christ, the head of a women is her husband, and the head of Christ is God" (as cited by Pihama, 2001, p.159).

The domination of European society (Walker, 1993) took a hold on Maori women. Christianity "destroyed the equilibrium between female and male elements" (Mikaere, 2003, p. 126). The writings of Best are abundant with Western theories and Christian messages of inaccuracy. The true messages contained within Maori cosmology have been misconstrued and re-interpreted. The process is described by Moana Jackson as an "attack on the Indigenous soul" (as cited by Mikaere, 2003, p. 68). In fact, what European writers did, was marginalise Maori women, by demoralising our spiritual and physical existence and by reinterpreting our role within the Maori worldview (Law Commission - Te Aka Matua O Te Ture, 1999).

The colonist's culture saw the worldview of Maori as 'heathen' assumed Christianity to be superior (Mikaere, 2003). Religion was used as an agent to humanise Maori from their 'heathen and savage ways'. This assumption was causal to the need of the British to convert Maori, as in their eyes Maori were a 'primitive' and 'savage' group of people (Mikaere, 2003). This is probably best defined by Judith Simon;

"while Christianity and civilisation were perceived as interdependent and virtually separate, Marsden believed that giving prior emphasis to civilising of Maori would enable the teachings of Christianity to be more favourably received"(as cited by Pihama, 2001, p. 205).

For Maori women our role of significance within the existence of humankind and within the metaphysical realm has been minimised to say the least (Mikaere, 2003). This is further reinforced through the work of Mikaere who states;

\footnotetext{
${ }^{3} 1$ Cor. $11: 3,7$
} 
"What the coloniser found was a land of noble savages narrating his/her stories of the wonder of women. Their myths and beliefs had to be reshaped and retold...in the retelling of our myths, by Maori male informants to Pakeha male writers who lacked the understanding and significance of Maori cultural beliefs, Maori women found their mana wahine destroyed" (2003, p. 71).

Religion was a precipitating factor to the displacement of our Maori expressions and beliefs with Best being one of the most renowned historical authors on this topic (Mikaere, 2003; Pihama, 2001). The missionaries' activities and the rapid conversion of Maori to Christianity had an extensive effect, with many Maori leaders becoming advocates of the Pakeha religion and way of life. This contributed to the breakdown of traditional and social structures of Maori (Walker, 2006).

The missionaries, supported by legislation condemned Tohunga from exercising spiritual practices important to traditional Maori life (Mikaere, 2003). The cessation of these traditional activities and practices demoralised the mana of Tohunga as Maori leaders (Walker, 2006).

As Maori, we cannot entirely blame the missionaries, we as Maori started to redefine our own cosmological beliefs by amalgamating some of their theories with our own (Mikaere, 2003), it was inevitable.

\section{The New Zealand Education System}

Prior to colonial contact, Maori had their own way of educating children. This is outlined in the previous chapter. With the arrival of Europeans in New Zealand, there became a need for the newly forming society to 'civilize' us as Maori (Leoni, 2009; Smith, L., 1993).

Colonial schooling within New Zealand gave the colonisers this very opportunity, and British women as the teachers were given the opportunity to 'civilise' Maori children (Seuffert, 2005). Teachers were expected to live in the region with Maori and to demonstrate in entirety, both in the school and in the region examples of "European family life, customs and civilisation" (Pihama, 2001, p. 219). Teachers were expected to teach the Maori children and the community how to live a European way of life. The intention was that Maori would replicate European ways of family life, and that the formation of nuclear families and their customs would eventuate. These customs included the gender based roles of the European family, where men were masters and women were subservient (Pihama, 2001). In fact schooling was seen as a way of humanising Maori (Pihama, 2001). 
The Native schools commenced with a foundation based on the English and Scottish education systems. Initially the missionaries conversed with children in Te reo Maori (Leoni, 2009). Slowly Te reo Maori was depleted within New Zealand schools in favour of English (Smith \& Simon, 2001). It was a method of civilising Maori and converting Maori to Christianity (Leoni, 2009; Smith, L., 1993). A system that was legally enforced by George Grey who expected education be religious, instructed in English and that teaching industrious ways were required in the Native schooling of Maori children (Pihama, 2001).

Schools were not established to benefit Maori girls, but to assimilate Maori girls. The expectation of the education system was to remove Maori values, beliefs and ways of life with what was deemed a more civilised way of life. This is evident in the curriculum, policies and legislation which surrounded colonial education for Maori girls (Pihama, 2001).

Within the Native school system, there was a clear distinction made between male and female educational opportunities. An example is the assumption that girls "lacked the innate ability" to undertake mathematics (Simon, 1994). Maori girls were offered schooling opportunities that reflected European societal perceptions rather than academic ability (Smith \& Simon, 2001). The curriculum was aimed at training Maori girls into roles of domestication (Mikaere, 1994; Smith \& Simon, 2001). Maori girls were to gain an education based on cooking, cleaning and needlework (Pihama, 2001).

Maori girls were raised to be wives and mothers, and were expected to return to their communities to set examples for the rest of the community. This saw many Maori girls academically underestimated and marginalised. Such roles and education for Maori girls were aligned with traditional Western beliefs and perceptions of the ideal society (Leoni, 2009).

Upon the completion of her education, a Maori girl could become a servant in a European home or, at best a Maori girl could become a teacher or nurse. And even these options became limited, due to the lack of funding available to Maori; and in nursing Maori could only nurse Maori patients, which further limited the need for Maori nurses (Johnston \& Pihama, 1993). A Maori girl's education was limited in its ability to offer vocational opportunities, and created a social class distinction (Smith \& Simon, 2001).

Boarding schools were private institutions under the control of religious groups (Pihama, 2001) and contributed to colonising Maori girls. Maori girls were removed from their whanau, hapu and iwi (Leoni, 2009). They were no longer immersed in Maori traditional ways, but were educated in Europeans ways of life (Leoni, 2009). It was a process of assimilation. 
In 1875, Hukarere Protestant Girls School was established for the purpose of providing "good Christian wives for the boys of Te Aute College" (Mikaere, 1994, p. 104). Maori girls were to become domesticated and civilised (Pihama, 2001).

While Maori wanted their children to have English knowledge (Leoni, 2009; Smith $\&$ Simon, 2001), it was not necessarily their intent to become colonised and to lose their own identity and culture. It was not long before resistance from Maori took place. Maori did not want their daughters to be educated as servants or low class labourers (Coney, 1993; Leoni, 2009).

It is unfair to state that Maori were not active in the promotion of education. Maori saw an opportunity to extend their own technology and knowledge through the acquisition of new knowledge, yet the European agenda for educating Maori was to replace Maori knowledge and bring social order and Christianity to Maori as a way of salvation (Simons, 1990).

Maori language and Maori culture was removed from the education system prior to the $20^{\text {th }}$ century. Legislation was causal to this with Te reo being ousted in the early $1900 \mathrm{~s}$. Children were punished for speaking Te reo at school and as a consequence by 1960 only $2.5 \%$ of Maori children could speak Te reo (Leoni, 2009).

\section{Urban Migration and its Effect}

Prior to World War 2, 90\% of the Maori population was still living in rural areas. In 1951, according to Census figures, $20 \%$ of Maori were living in the cities. Within 30 years $80 \%$ of the total Maori population were living in the cities. The 1961 Hunn report was instrumental in the urban movement and soon Maori were moving for 'improved levels of health and living standards'.

During this period many Maori lost their identity and their cultural sense of being. The traditionalism of being Maori did not factor into urban living (McLennen, Inkson, Dakin, Dewe, \& Elkin, 1987). Urbanisation saw the depletion of collectivism as it was traditionally exercised by Maori and saw the European approach to individualism and the 'nuclear family' become a way of life for many Maori (Mikaere, 2003).

This had calamitous effects on Maori, with parents now child rearing and birthing their children alone - a role traditionally bequeathed upon the hapu (Mikaere, 2003). The fundamental principle of whanaungatanga was soon reduced. Whanaungatanga is a process that is inclusive of our whakapapa and embraces relationships (Mead, 2000). A process that includes not only our connectedness by blood but also through our whenua, a connection that is made strong through our whakapapa (Mikaere, 1994). In child rearing, 
whanaungatanga provided support, help and nurturing for the child (Mead, 2000). Whanaungatanga was the responsibility of the collective and Maori were collectively responsible for child rearing.

Another example given of urbanisation and its effect upon whanaungatanga and the Maori worldview is tangihanga. For Maori if someone close to the whanau or hapu died you were expected to attend the tangi for three days. Maori were advised by the then Southern Maori MP, Mrs Whetu Tirikatene-Sullivan not to take tangihanga leave above their annual leave entitlement as Maori would be classified as a high risk in employment (McLennen et al., 1987). This is still a concern for Maori (Mahuika, 1975). The process of exercising whanaungatanga was undermined through the lack of attendance at tangihanga. Maori were unable to support each other, in the traditional ways of tikanga. The limitations of exercising whanaungatanga due to isolation has contributed to the loss of identity, sense of belonging and knowledge for Maori (Mikaere, 2003).

For many Maori, success has come from living in the cities. Many have done well in business, on their own, but sometimes at the expense of their culture, identity and connectivity to the whenua and whanau. Urbanisation was instrumental in seeing some Maori disassociated with Maori culture and practices (McLennen et al., 1987).

\section{What Happened as a Consequence of being Marginalised?}

The historical impact of colonisation that undermined Maori women continues to effect Maori women socially and economically today. Assimilative policies, legislation and practices have weakened Maori ways of life, Maori worldviews and Maori identity (Pihama, 2001).

Maori women continue to suffer from low income, poor health and overcrowding and are more likely to be unemployed (Law Commission - Te Aka Matua O Te Ture, 1999). Education as a key determinant has contributed to the social and economic status of Maori women. Not only does this affect Maori women, but these very effects are intergenerational, causing ongoing issues.

Today many Maori women return to education as second-chance learners in search of educational qualifications. Yet social and economic disparities can cause difficulties in Maori women being able to re-enter and maintain education. Statistically, Maori women are twice as likely as non-Maori women to be living in one parent home with dependents, thereby reducing their opportunities to access employment and education opportunities. For many Maori women this has left them feeling 'powerless' (Mikaere, 2003). 
From a contemporary perspective, there have been changes in educational policy, yet monoculturalism, as a practice continues to operate in the New Zealand education system. In doing so, education continues to influence our societal beliefs and conception of the world. This has become the 'status quo', a rationalised and accepted norm, a systematic process of continuity.

In New Zealand, social stratification advanced European culture and tradition, and classified the Maori worldview as less significant. It is a Eurocentric perception of the world that saw Maori values, systems and beliefs undermined. As a consequence, the fragmenting of Maori identity and knowledge in favour of a dominant knowledge and ideologies of Western culture marginalised Maori women (Pihama, 2001).

\section{Summary}

Many Maori women continue to see themselves in a negative light. It is consequential to the processes of colonisation and imperialism. Maori women were ousted through systems that saw their cultural ways being diminished through legislation, education and religion (Mikaere, 2003; Smith, L., 1993).

In this chapter the objective is clearly defined in the following quote, "If marginalisation is about being pushed away from the centre, then it is timely that we pushed back" (Ormond, et al., p. 194). This chapter has been about conscientisation (Freire, 1995). It is about our future as Maori women. It is about pushing back.

Paulo Freire (1995) reminds us that as oppressed people, we can overcome oppression by thinking critically and taking transformative action. In this chapter I offer the opportunity for Maori women to critically think and to take transformative action.

Western ideologies bought with them class structures, gender discrimination and racism (Pihama, 2001). These are all structures that formalised the process of 'dehumanising' (Freire, 1995) or 'othering' (Foucault, 1964) Maori women. They contributed to the hegemonic discourse which Maori women have endured.

Maori women have been pushed to the periphery of society through the ethnocentric actions of Western civilisation. It was inevitable that Maori women would become marginalised. In applying education, religion and legislation as tools used upon Maori women to dehumanise us, I have demonstrated three key areas of loss for Maori women and how this came about:

- Maori women and their identity were seen as less significant, even invisible in some instances through education, legislation and religion; 
- their knowledge base, matauranga Maori, was undermined, re-interpreted and for some, it was destroyed through religion, education and legislation; and

- Maori women lost their connectivity to their whenua (a sense of belonging) endowed to them through whakapapa, through hegemonic discourses directly associated with religion, education and legislation.

Pihama (2001) links the influence of colonisation and imperialism to loss of the physical, emotional, spiritual and intellectual positioning of Maori and, in particular, to the role of Maori women and the weakening of our position based on the reclassification of our relationships and roles within society.

Now that we have had the opportunity to critically think (Freire, 1995) about the impact that colonialism and imperialism have had upon us, we can now begin to resist (Bargh, 2007) and decolonise ourselves as Maori.

The next chapter looks at 'liberating education' (Freire, 1995), a term used to discuss the opportunity in which education can be a transformative tool to empower and liberate Maori women by enabling them to reclaim their identity, matauranga Maori and sense of belonging. 


\section{Chapter 5: Identity, a Sense of Belonging and Matauranga Maori Introduction}

This chapter is about how Maori women can resist colonisation and engage in transformation. Whilst education has been a large part of the assimilative process that imposed hegemonic discourse on Maori women (Simons, 1990), education could offer a way forward in which Maori women can free themselves. The work of Freire (1995) has been crucial to New Zealand academia as an informant of transformative action for Maori women. hooks (1994) reminds us to be vigilant and committed to creating an education system that embraces cultural diversity.

The history of education in New Zealand was damaging to our identity, our knowledge and our sense of belonging as Maori. In this chapter I discuss the relevance of a sense of belonging and matauranga Maori in relation to the formation of a Maori identity. Each of these factors are intertwined and form a basis for understanding how we as Maori define ourselves.

Our epistemic knowledge base as Maori was misinterpreted in favour of an alleged superior philosophical knowledge base (Bishop, 1998). The New Zealand education system operated from within a monocultural context, that embraced one truth - a believed superior truth. The believed truth is one that was enforced through education and replicated within society (Law Commission - Te Aka Matua O Te Ture, 1999).

Maori women were marginalised through the systemic processes of colonisation and cultural imperialism. Education played a large part in pushing Maori women to the exterior of society (Pihama, 2001). The dissemination of Western ideologies contributed to the undermining and denial of Maori women's rights, not just in Western society, but soon enough within our own society (Pihama, 2001).

Part of resistance is understanding that as Maori women who challenge the Westernised concept of Maori identity and the roles of Maori women, we face scrutiny not only from Europeans but from our own who have accepted the colonisers' Western ideologies (Johnston \& Pihama, 1993; Stewart-Harawira, 1993).

In the latter part of the chapter I explain how education could be instrumental as a transformative process for Maori women in becoming decolonised. Whilst Maori continue to struggle within the education system (Pihama, 2001), Smith (1993) reminds us as Maori women that our struggle is about gaining space. Maori women, as oppressed people must actively participate in becoming 'humanised' (Freire, 1995). We as Maori women need to reclaim our 'humanness' through transformative action. 


\section{What is Maori Identity?}

"The future of our people cannot be stereotyped by our current versions of Maoriness...None of us is today what our ancestors were, and our descendants will not be like us. With aroha, knowledge, strength, commitment and politicisation our descendants will be Maori, their way...Our work as today's version of Maori is the same as that of our tupuna: to continue our story, to strengthen it according to our times and to add the next chapter. That will be done" (Ramsden, 1993 as cited in Borrell, 1995).

Even though our ability to identify as Maori today may not be the same as our tupuna, the assertion of Maori identity has survived colonisation. Maori have demonstrated that they have the ability to 'self-identify' as Maori. Whilst this is seen as problematic (StewartHarawira, 1993), what is important is that, Maori have maintained an identity (Borrell, 1995; Penetito W. , 2010).

Through being colonised, Freire (1995) notes that the lack of identity and selfaffirmation denied people the opportunity for humanness. Maori became oppressed through the denunciation of our own cultural identity. For many Maori, the loss of lands destabilised our identity (Moeke-Pickering, 1996). Today, what remains important is that "the formation of a secure identity is likely to contribute to an overall stable Maori identity" (MoekePickering, 1996, p. 10).

The complexity for Maori women in defining ourselves becomes further complicated through gender. Assimilation, saw our rights as Maori women undermined in the interest of forming one dominant race, a European race (Johnston, P., 1998). Legislation was a critical component to marginalising Maori women. Our identity as Maori women was either that of 'the other' or that of 'his other' (Johnston \& Pihama, 1993). We were oppressed, not only because we are Maori, but because we are women (Johnston \& Pihama, 1993). In fact, it made Maori women invisible. The colonisers' legislation was a system where Maori women did not have a voice, nor did we have an identity (Coney, 1993).

Maori identity today has been complicated by colonisation and its assimilative process and has seen many try to define what Maori identity is. In determining a mechanism to define Maori identification:

1. Culture has been applied to mean, learned aspects of life which differ from other groups - aesthetics' such as the arts and the way in which we perceive the world (Metge, 1990). 2. Race as a determinant of identity has been discredited by many due to a lack of 
validity in assessing identity through physical appearances such as skin colour, hair, facial feature (Littlefield, Lieberman, \& Reynolds, 1982) and,

3. Ethnicity is a widely used mechanism for describing identity as it can permit multiple ethnicities, yet caution needs to be applied to ethnicity as an identifier as it can force people to choose one ethnic group over another (Schwimmer, 1966). Each of these determinants permit for membership to a social group to inform them of their identity

As Maori we have demonstrated our ability to possess multiple identities (Ballara, 1998), we can identify as individuals or as part of collectives or as referred to by Durkheim (1997) "collective consciousness". Collective consciousness is "the totality of beliefs and sentiments common to the average members of a society" (Durkheim, 1997, p. 79).

Ballara (1998) adds to this notion of identity, recognising the significance of the social relationships of whanau, iwi and hapu as interconnected and contributory to the 'multiple identities' that Maori have managed throughout time. This notion is supported by the work of Metge (1995) who also acknowledges that Maori have interrelated relationships that contribute to their identity. Penetito (2005) acknowledges three determinants that work together to form a Maori identity, each interrelated with the one another: Maori identity, cultural identity and whanau identity

According to Durie (1994) securing an identity from within a Maori context is paramount to achieving the goal of self-determination. He adds that self-identification as Maori requires cultural knowledge, access and participation in things Maori, inclusive of Te reo as significant contributors to a Maori identity. His interpretation of a Maori identity is deepened by the level of participation, awareness and relationship which Maori have within these areas. For many Maori, colonisation and urbanisation prevented them from acquiring the required knowledge, ability to access, and the participation in all things Maori, which had dire consequences. This was a double-edged sword for Maori women. We were further alienated as legislation and Western societal perceptions saw us as having even fewer rights, and in some instances no rights (Mikaere, 2003).

Durie (1994) says there is no tool applicable to measuring the concept of 'being Maori' and that it is an evolving process. However he offers an opportunity for defining Maori identity, giving three options:

1. Cultural Maori - Maori who understand whakapapa, te reo and tikanga,

2. Bicultural - A group of people who identify as Maori but are able to operate among Pakeha and lastly;

3. Marginalised - Maori who are unable to relate to Maori or Pakeha 
Williams (2000) concurs with Durie's definition, giving a similar understanding. The first is 'traditional Maori core', followed by 'primarily urban' and finally 'unconnected'. Durie (1994) adds that identity continues today to be influenced by social, political, ecological environmental factors and is yet to be defined satisfactorily. Rangihau (1975) shares the notion that 'being Maori' through the process of participation forms your own cultural identity.

Another model of Maori identity developed by Pere (1988), encapsulates six core fundamentals, yet she suggests vigilance when defining what Maori identity is:

1. a relationship with the whenua - a sense of belonging,

2. spirituality - a sense of meaning or purpose,

3. whakapapa - an ancestral connection,

4. tikanga - ability to maintain Maori customs and practices

5. kinship - obligation to the people; and

6. humanity - a sense of belonging to the wider community

Rangihau (1975) cautions about identity being linked to the term 'Maori' as it is a created identity formed by Pakeha. He calls for an identity relevant to iwi - a cultural identity. Maori in its traditional sense has been coined by British colonisation, it is a term in its origin which meant 'natural' (Broughton, 1993).

Colonisation in New Zealand has seen the identity of 'Maori' being classified by Pakeha and legislation. The legislative identity was almost always based on the amount of Maori blood a person had and often inferred that a Maori was a male only. Very little defining of Maori identity aligned with the traditional ways in which Maori identified themselves. Traditionally the identity of Maori was connected to their cultural beliefs and social norms through their land and whakapapa (Borell, 2005). Each of these indicators of identity is intrinsic with a sense of belonging and forms a relationship with place.

Unfortunately for Maori, Ausubel (1973) offers two dismal consequences, made real by the effects of colonisation and imperialism, for the future of Maori and our identity. Either be absorbed into the Pakeha race or to be underprivileged second-class citizens that are recognised in the framework of New Zealand society through economic, social and political life as a marginalised or disadvantaged ethnic community.

Through the process of colonisation many Maori have lost their identity and their cultural knowledge, and their ways of being have been reshaped by Western concepts (Borrell, 1995). The very denial of our cultural ways of knowing and being is a "denial of 
our right to be fully human" (Pihama, 2001, p. 61). This in turn has created another form of Maori identity.

As Maori women we need to disassociate ourselves from the negative identity that sees us as invisible and reclaim our identity by reasserting our role as mana wahine. Acknowledging how we have been marginalised and how this has impacted on our identity engages us in systems for transformation (Mikaere, 2003).

Maori have to choose their destiny, to be assimilated, to be a second class citizen or to break the mould and resist colonisation (Bargh, 2007). The basis for this change will only be created by the transformation of 'Maori by Maori', or as Freire (1995) asserts, transformative action is the role of the oppressed to undertake. It is for us as Maori to initiate and drive.

\section{What is a Sense of Belonging?}

"The place itself or the objects in the place can remind of one's past and offers a concrete background against which one is able to compare oneself at different times. . . This creates coherence and continuity in one's selfconceptions" (Korpela, 1989, p. 251).

Like many indigenous groups, our sense of belonging as Maori stems from our connection to the whenua and time (spatio-temporal). Our connection to the whenua is tied to our tupuna and our epistemological belief system (Binney, 1984). Mead (2003) concurs with Binney, informing that whakapapa, genealogical connections to place are all part of our identification mechanisms as Maori.

The analysis of 'place' has been given great emphasis throughout a vast array of disciplines. Anthropologist Bourdieu (1971), cultural geographer Tuan (1974), and sociologist Hummon (1992), have all written about place and the relationship between identity and place. Cameron (2004) explains that place connects people creating a critical awareness of their environment. Malpas recognises the relationship between place and identity, "To have a sense of one's own identity... is to have a sense, not of some simple underlying self that is one's own, but rather of a particular place in the world"(as cited by Cameron, 2004, p. 4). For many Maori being disconnected from the whenua and cultural identifiers, has prevented them from having a sense of belonging, causing impact upon their ability to identify as Maori. As Maori our identity was secured in the cycle of life. We come from the whenua, we return to the whenua. It is our whakapapa, it is our knowledge.

Through Maori epistemology, we are grounded with Papatuanuku. Through our connection to the whenua we form a sense of belonging. Our whakapapa as Maori informs 
us of who we are. This is defined by Pascual-de-Sans, "The lives of people and the lives of social groups become intimately related to the places where they live, and where their ancestors lived" (2001, p. 2). Pascual-de-Sans further adds that "everything and everyone owes their existence to ... and can even be considered to be a product of ... the time and the space in which they exist" $(2001$, p. 2). For Maori this is intrinsic with the concept of whakapapa. Our epistemological world view is one that is constructed by us as Maori to inform of our world and our sense of being. Peter Sharples offers his contribution;

"Everything Maori did - the persons relationships with their own family, with their society, with the world, with the land, with the sea, with space itself - everything was, you could say, a Maori worldview.” (Sharples, 1994, p. 12).

As Maori women we are reminded that our identity and sense of belonging is connected to topographical signposts such as the rivers, lakes, mountains, seas and forests (Evans, 1993). Our identity as mana wahine is embedded in our epistemological beliefs and our whakapapa - each being connected to the whenua and crucial to our sense of belonging.

\section{What is Matauranga Maori?}

In times prior to European settlement in Aotearoa, Maori epistemological knowledge was the only form of knowing (Sharples, 1994). The progression of colonisation privileged Pakeha knowledge, pushing Maori knowledge to the periphery (Pihama, Smith, Taki, \& Lee, 2004). The writings and recordings of New Zealand history have been detrimental to both Maori and non-Maori. Many of the misconstrued historical accounts have been endorsed, based on the writers' perceptions of our lives and their opposing world views (Bishop, 1998). Our knowledge base and lived experiences have been reframed, reinterpreted, reclassified and redefined (Pihama, 2001). The questioning of matauranga Maori is due to Western beliefs of what counts as knowledge. The quest for the validation of Indigenous forms of knowledge is not unique to New Zealand; it is an Indigenous worldwide issue (Smith, L., 1999).

From early historical times education was important to Maori. Maori had formal places of learning; whare wananga or whare kura (Hemara, 2000). The curricula was specific to the "spiritual, intellectual, social and physical wellbeing of the community and the individual" (Hemara, 2000, p. 40). The Whare was where our knowledge or Maori episteme was handed down. These institutes of learning also had a whakapapa that extended from the metaphysical world. It was where our knowledge and the baskets of knowledge were held (Best, 1934). 
Traditionally, even before birth Maori were educating their children. Oriori, waiata, whakapapa and karakia would be recited to the unborn baby to tell them of their connection to their iwi, hapu, whanau and the whenua (Hemara, 2000). Education was a collaborative approach. The hapu was responsible and collectively they played a role in developing the whole person. Kuia, Kaumatua, Maori men and Maori women were crucial to education, they were competent in transmitting various forms of knowledge, both formally and informally (Heuer, 1969; Sharples, 1994).

Whare wananga and whare kura factored in the necessity of life through systems of learning and knowing such as memorisation and oral recollection, and the teachings were specific to matauranga Maori (Dakin, 1996). Prior to colonisation education within these whare was delivered by Tohunga who held the knowledge and shared that knowledge through oral and practical activities (Hemara, 2000). This knowledge and the education provided by the Tohunga was in accordance with matauranga Maori. As Maori learners we were involved and actively participated in the learning process. Maori learnt through active group learning, informed by matauranga Maori and delivered by whanau from within both a formal and informal learning context (Hemara, 2000). It wasn't until the settlement of Europeans that written methods of teaching were incorporated as a method of teaching (Dakin, 1996). A method of learning, which Maori grasped quickly and built into their repertoire of skills (Hemara, 2000).

Matauranga Maori needs to be incorporated into the mainstream New Zealand education system in a way that supports lived cultural experiences (Saunders, Brabham, \& Ferguson, 1993). The refusal of the New Zealand system to proactively implement matauranga denies Maori their humanity (Pihama, 2001).

Maori must also be cautious of how matauranga Maori is implemented into the education system as it must be questioned - what are the benefits for Maori? While Pakeha may gain our knowledge, what do we gain and how do we know it will not be subjected to further discrediting? (Pihama, 2001).

The ability to effectively implement matauranga Maori into the education system requires the active participation and utilisation of community and whanau as an integral part of the school community. The role of whanau and the community is more significant than ever in providing matauranga Maori as a stimulus for education. Bawden (1991) discusses, a system for learning that supports community and active participation as collaborative approaches to education, a pedagogy known as Critical Learning Systems (CLS). 
The denial of matauranga Maori or the lack of ability for schools to teach and practice matauranga Maori today could be overcome by utilising whanau. It would be a community based initiative to instil the values and knowledge of 'being Maori' in a holistic manner. This lack of ability or denial from the education system has been instrumental in assimilating Maori (Pihama, 2001).

The important position of whanau in the development of the individual is significant in validating whanau as educators. This is best defined by Professor Kidd in, The Kiwi fight back (McDonald, 1986, p. 112);

"I suppose it will be generally agreed that education is essentially the training of the young for adult life. The Latin word, educato, is a metaphor from the feeding of infants until they can feed themselves independently, and, as Varro says Educare is the verb that goes with the noun nutrix...It must be the claim of all educational systems in all ages that they prepare the young for the kind of life they may be expected to live when they grow up" (1986, p. 112).

Education is an on-going process and life long process. It encompasses the "whole cycle of a person's life" (Sharples, 1994, p. 18). We continue to learn through experiences, participation, observation and listening. The following quote is also suitable in recognising the significance of experiential knowledge and culture, "Culture cannot be learned from a text book. True understanding and appreciation are possible only from first hand experiences" (Tauroa \& Tauroa, 2005, p. 13).

The value of the community and whanau as resources that can positively contribute to the development and learning of students has been recommended as a step forward for many decades. Schools within New Zealand have failed to embrace this concept at any great pace.

\section{How can Education Contribute to the Transformation of Maori Women?}

The unrelenting failure of the education system within New Zealand is that it continues to deliver inequality for Maori girls. Such inequalities have continued to plague New Zealand society and have put many Maori girls at the 'bottom of the heap', leaving them feeling alienated and dumb (Smith, L., 1993). Our destiny as Maori women lies in our capacity to transform education and society, as the current societal beliefs continue to affect us as Maori women (Mikaere, 2003).

Freire (1995) tells us that transformation is action, reflection and resistance orientated. In the Pedagogy of the Oppressed, Freire (1995) calls for an awakening, or what 
he coins 'conscientisation' a term which engages us in deliberation leading to resistance, a process of resisting perceptions and oppression. For Maori women, decolonisation emerges from becoming conscientized (Stewart-Harawira, 1993). Yet the process of being decolonised is one that challenges Maori women to reclaim their role and identity. The challenge for Maori women is not simply confronting race and class. It is further complicated by the colonised Western beliefs of gender roles and identity (Mikaere, 2003).

Maori have demonstrated how we can resist colonisation through the development of educational initiatives. The use of matauranga Maori and kaupapa Maori as frameworks for learning have been exercised in the development of Te Kohanga Reo and Kura kaupapa Maori. These initiatives are a fundamental stance towards Maori creating positive changes in education that benefit Maori, New Zealanders and the world through the retention of Maori knowledge, culture, language and values (Sharples, 1994). While this provides an avenue for Maori knowledge and an alternative education system for Maori, it is a single option. These initiatives were driven by Maori outside the education system, and evolved as a 'resistance' to the education system (Smith, G., 1991). This change was a stance that Maori communities grasped as a confrontation to societal, political and economic issues that were impacting on Maori. The role of Maori women as active participants in the development Te Kohanga Reo and Kura kaupapa, such as Katerina Mataira must be recognised, as it is women like this who have maintained our mana wahine and our whare matauranga for future generations (Mikaere, 2003).

Gruenewald (2003) offers an educational approach for Maori that would enhance and/or acknowledge our sense of belonging and identity. He believes that critical theory and pedagogy permit people to understand colonisation and its injustices. By understanding colonisation and its effects transformation is enabled, offering an educational process for decolonisation to take place (Smith, L., 1999). Sobel, defines decolonisation as the "process of cultural and historical liberation; an act of confrontation with a dominant system of thought" (as cited by Gruenewald, 2003, p. 9).

In an educational capacity a sense of belonging becomes a key learning component through utilising place-based education as a teaching pedagogy. Place-based education enables the interactive relationship between the school, its pupils and its community (Smith, G., 2002). Local knowledge, experiences and experts are imperative to the pedagogy. This engagement enables the student to understand, within their own community how they contribute to their society and how they make a difference. As an informed society the community has the ability to make informed choices, processes where reinhabitation 
(Gruenewald, 2003) and decolonisation are options towards transformation. For Maori, Gruenewald offers us an opportunity to reconnect with our whenua and enables our knowledge of the whenua to be validated from within the education system, through our lived experiences.

Part of placed-based education as a critical theory is acknowledging that the student has knowledge from experiences outside the classroom environment which are beneficial and extend the process of learning. It promotes an environmental consciousness and a selfconsciousness through engaged activities that involve active participation with the environment, its resources, the local community, experiential knowledge and narrative (Cameron, 2004) as tools for learning. Kawagley advocates that an environmental consciousness and self-consciousness create a sense of responsibility which he terms, 'Heart Talk', a concept defined as “a love for self, a love for others, and a love for place, giving one a sense of responsibility to take care of oneself, to care for others and the environment that one lives in" (2000, p. 102). A sense of responsibility to the whenua is very much part of Maori identity and our sense of belonging through our knowledge base: matauranga Maori.

Oriori, waiata and karakia are all vital to dispersing matauranga Maori and educating people on local areas. These are all ways in which Maori women can contribute to the education system. Through active participation, Maori women can challenge the current knowledge base and assist with legitimising our knowledge base. This is about situating ourselves as Maori women, with the overall objective of acclaiming our role as mana wahine (Smith, L., 1993).

\section{A Pedagogy that Promotes Transformation}

In order to demonstrate how education can be a tool for transformative action, I draw primarily on the work of Emeritus Professor Richard Bawden. Bawden was the Dean of Faculty of Agriculture and Rural Development at the University of Western Sydney, Hawkesbury, for 40 years. He retired (August 2007) as a Visiting Distinguished University Professor at Michigan State University. He is both a Theorist and a Practitioner of his theory. He was appointed to the Membership of the Order of Australia (AM) in 2000, in recognition of his national and international work in systemic development.

In addition to his academic posts, Richard Bawden is a Foundation Director of Global Business Network Australia (GBNA) and of the Systemic Development Institute (SDI), and is a Senior Consultant with the Neville Freeman Agency (NFA) in Australia.

In applying Bowden's theory I propose to explain the following dimensions, with the support of other theorists: 
- $\quad$ Praxis - "a dynamic system of learning, generated by the interaction between theory, practiced and praxis";

- Ways of knowing - epistemology, ontology and axiology;

- $\quad$ Sub systems of knowing - meta praxis and epistemic praxis; and

- $\quad$ Critical learning systems - a group learning system.

Bawden's system of learning engages students in learning that is localised and community based. Bawden's provides an educational process where situational learning (Vygotsky, 1978) and place based education interact with each other in order for students to learn about the world around them through lived experiences. This type of learning system is not uncommon for Maori, it is how we learnt traditionally (Hemara, 2000). Regardless of what we do as Maori, we need to let go of the past in order to engage in new paradigms, we need to become free to move forward and take transformative action.

\section{Understanding how to learn}

Bawden (2005) explains through the work of Maturana and Varela (1988) that the ignorance of not understanding the concept of knowing causes us to be blind to our own lives. Colonisation has caused us to be blind to our own lives, through redefining our ways and beliefs (Johnston, P., 1998). In fact, this is best defined by Freire "The person who is filled by another with contents whose meaning she or he is not aware of, which contradicts her or his way of viewing the world, cannot learn because she or he is not challenged" (1974),

For Maori women, this is part of 'resistance', understanding how we know what we know and valuing our knowledge base as Maori women informs us how we can move forward in becoming 'decolonised'.

By understanding how we know what we know, we begin to understand the acquisition of knowledge and the limitations of knowledge. Bawden (1991) defines epistemological knowledge as a way of understanding and making sense of knowledge. Whilst ontological knowledge is recognised through fact and theory, epistemological knowledge is often founded in systems of culture, history or religious beliefs. Bawden's system for knowing briefly mentions ethics, axiology. This, though briefly written, is significant to his system for being as it is a branch of knowledge that deals with moral principles that assist us with determining what is good and bad or right and wrong. Bawden states, "in becoming me, I learn to decide what I think is wrong and what is right, as an ethical stance" (1991, p. 3). Whilst Western world determine ethics through an English 
perspective, Maori utilise tikanga to determine what is right and wrong. How we undertake this is determined by the kawa (Mead, 2003).

The significance of knowledge is fundamental to Maori/Indigenous pedagogy as it is often these understandings of the world, the fact and theory and the morals that are questioned from within a Western context (Smith,L. 1993). In legitimising our knowledge as Maori, our beliefs, values and practices need to be recognised as authentic. A cognitive approach to development requires that the social depiction of the Maori worldview, in accordance with matauranga Maori, be recognised as valid.

The tragedy within traditional academic institutes is that the pedagogies and curricula did not recognise the distinction of each level of learning, and in fact were informed by Western institutional norms and beliefs (Gidden, 1994). We learn from Bawden's work that academic institutes recognise 'one reality' and that such a reality was identical for all learners. Traditionally this is evident in the New Zealand centralised education system, not everyone can achieve. Education was set up in New Zealand to be a European reality, a system normal to Pakeha children (Penetito W. , 2010).

Orr (1992) adds credibility to this by taking the stance that the misconception of the world is founded on the domination of nature through the fragmentation of reality, causing the world to be perceived as a mechanism, the separation of observers and the observed. Pihama also acknowledges this as "instrumental in the colonising process and is based on an intention of alienation and fragmentation" (2001, p. 68).

Bawden (1991) stresses that in order to transform the current state of education; we need to move away from the 'Binary Trap' of dualistic thinking to a holistic way of thinking. For Maori holistic thinking is not uncommon and for many Maori it is still a preferred method of learning. Being solution based, Bawden (1991) cites Maturana and Varela (1988) "we must learn to bring forth new worlds together" (1991, p. 2). Bawden's contributions to new worlds and ways includes his praxis, a three-dimensional approach to learning that encapsulates theory, practice and praxis; “an ever unfolding praxis” (1991, p. 2).

\section{Praxis}

In opening his paper Bawden (1991) uses the following quote from Henryk Skolimowski (1985), a Polish Philosopher;

"Wholeness means that all parts belong together, and that means they partake in each other. Thus from the central idea that all is connected, that each is part of the whole, comes the idea that each participate in the whole. Thus participation is an implicit aspect of wholeness" (1991, p. 1). 
I believe that Bawden applies 'wholeness' in his work to the 'essence of being' as a system for knowing. Like any system, each whole interacts with the whole in order to create wholeness.

For us as Maori, we can liken this to our whakapapa, each part interacts with each other. The landscape, our past, our present and our future work together to create our wholeness as Maori. We as Maori are part of the world - our whakapapa starts from our metaphysical formation, and informs our 'essence of being' as Maori. Through our whakapapa, various parts of our Maori pedagogy are interrelated and inform each other. "Whakapapa, waiata, korero tawhito and whakatauaki do not exist in isolation...while informing each other, each one can also extend its boundaries of enquiry, both individually and collectively" (Hemara, 2000, p. 33).

Bawden provides the following definition, "My Praxis is a system for being me, and in learning about that system, I learn how to learn systemically" (1991, p. 3). There is a clear message that the system of knowing is one where the individual's interaction with society assists with the creation of a praxis for being. This system for knowing is coupled with knowledge from outside events, theories and practices and the individuals own intuition, thoughts, beliefs, reasoning and logic. It is a system that Maori understand. It is the way we learnt traditionally. This latter definition by Bawden clearly defines praxis as, “... both the process by which I exploit this relationship between practice and theory as well as providing the context for it" (1991, p. 3). For Maori education is a lived experience (Sharples, 1998).

For Maori our events, theories, practices, intuition, thoughts, beliefs, reasoning and logic are informed through our way of knowing the world, our truth or system for knowing (Sharples, 1998). This exemplifies Bawden's (1998) way of being, as a way of knowing and a way of doing. As Maori women we were teachers, we were leaders, we learnt from our environment, our people, our stories and through our knowledge; matauranga Maori.

Bawden also acknowledges the work of Freire (1995) in defining praxis as the "reflection and action on the world, in order to transform it" (1991, p.3); a system of "critical consciousness'. Cieskowski (1838) defines praxis as "willed in action by which theory or philosophy becomes transformed into a social actuality" (as cited by Bawden, 1991, p. 3). All of these theorists talk of the connection between experience, learning and democracy (Bawden, 2005). 


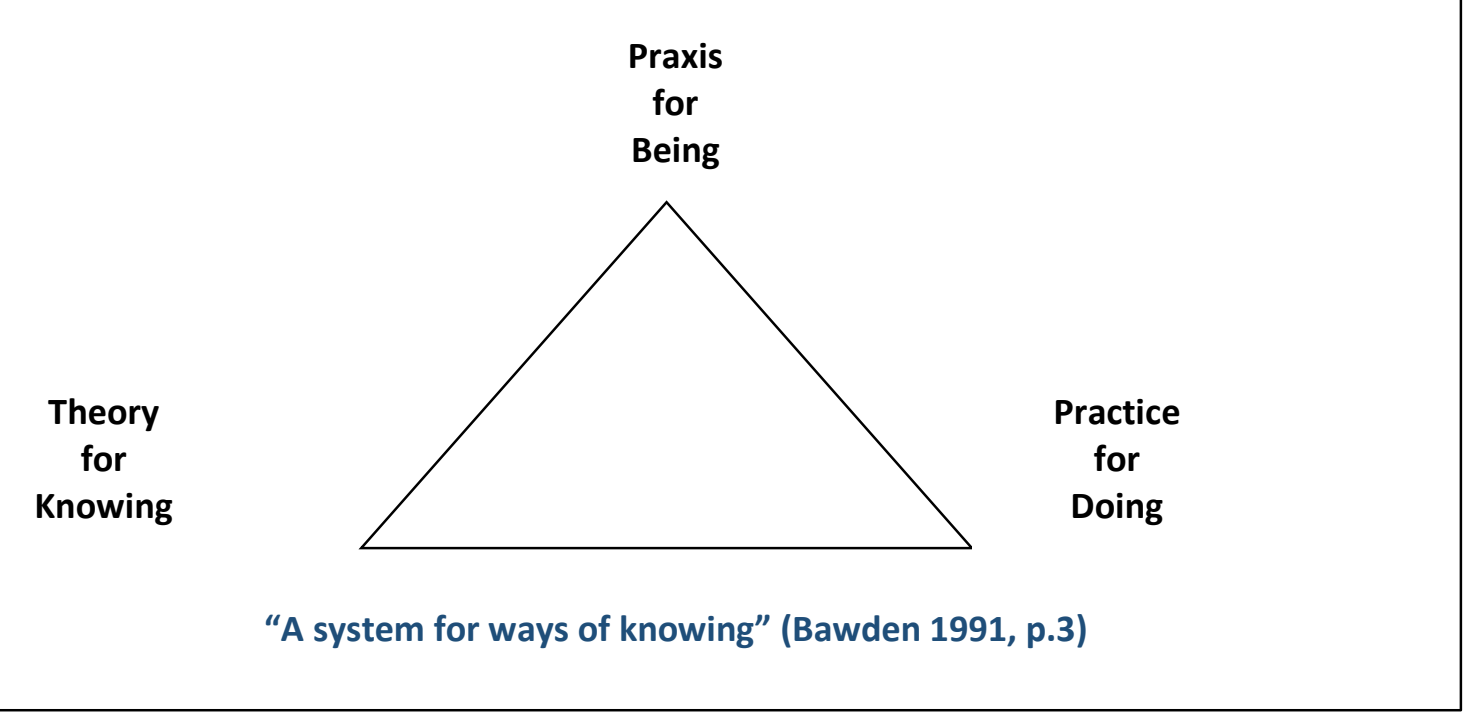

Bawden (1991) notifies us that the processes of experiential knowledge, propositional knowledge and practical knowledge as collectives contribute to a system of knowing. Praxis is a system whereby each component is interconnected and contributes to a trinity of knowledge, creating a 'dynamic system of learning'. Bawden utilises the earlier work of Reason and Heron (1986), to define three kinds of knowledge:

- propositional knowledge; a knowledge usually formed through theory or fact,

- practical knowledge; a knowledge base founded by physical action or doing and finally,

- experiential knowledge; a knowledge resulting from the transformation of personal experiences.

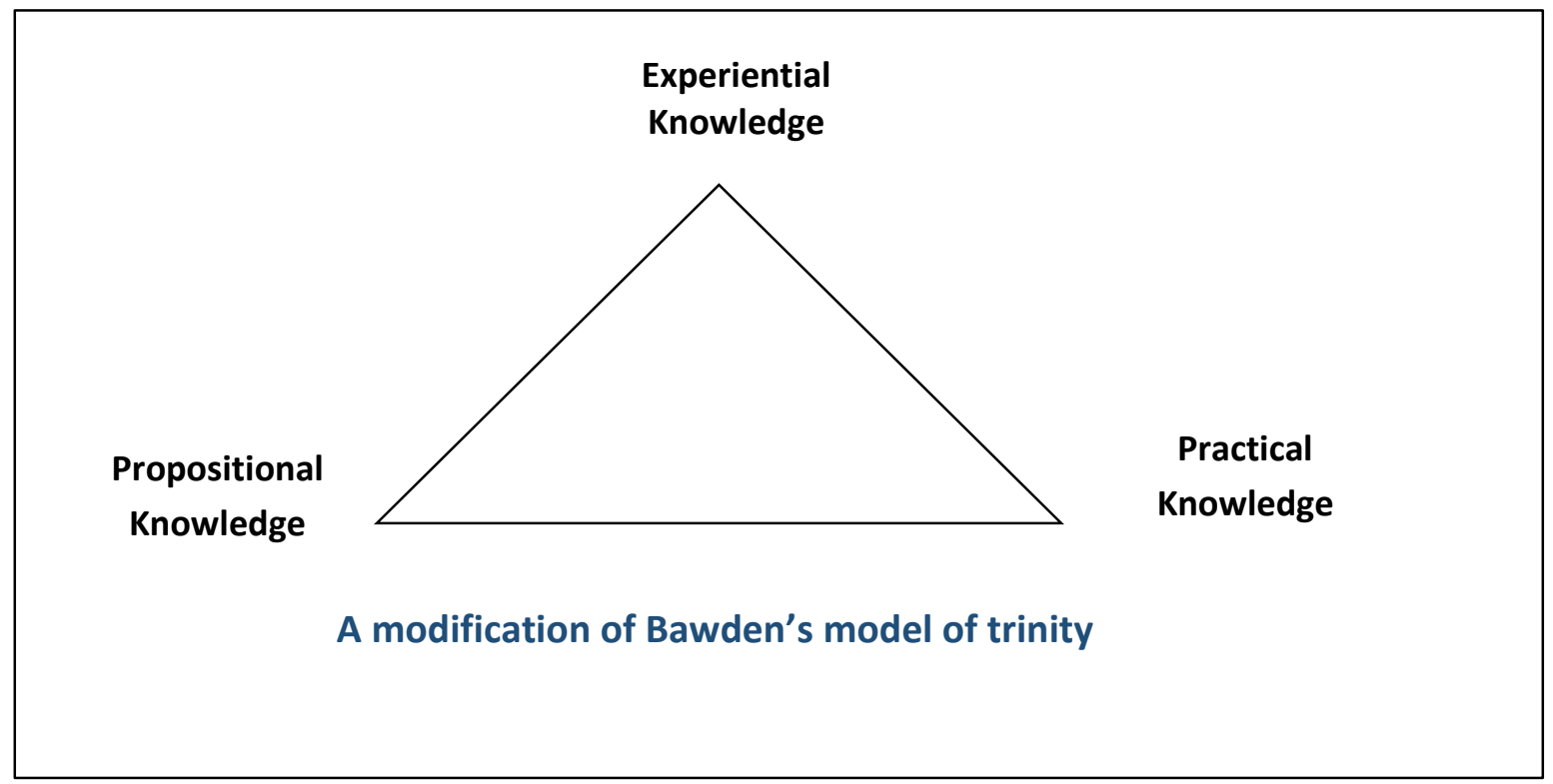


As an extension to the work of Bawden (1991), Heron's (1992) discussion on personhood becomes relevant to Bawden's 'Praxis for Being'. Epistemology and how we know what we know is grounded in the belief that 'feelings' as defined by Heron are a "grounding level of personhood" (Heron, 1992, p. 1) and is relevant to the process of knowing enabling participation and engagement in learning. While there is a direct link to the theory of co-operative inquiry, Heron looks at the relationship of being and in particular the association of feelings as an integral part to the process of learning. Heron and Reason discuss the process of 'critical subjectivity' as;

"an awareness of the four ways of knowing, and how they interact, and the ways of changing the relationships between them so that they articulate a reality that is unclouded by a restrictive and ill-disciplined subjectivity" (Heron \& Reason, 1997, p. 281).

The four ways of knowing are briefly described as:

- experiential knowledge- a form of knowledge that is influenced by personal experience,

- propositional knowledge - a knowledge founded on theory often related to logic and evidence,

- practical knowledge - a process of knowing that is developed through knowing how to do something through practical application and;

- presentational knowledge - a knowledge that bridges propositional and experiential knowledge through spatiotemporal patterns of imagery and sounds.

Presentational knowledge is reliant on our senses and very relevant to Maori as it could include our way of knowing through our arts, our culture and our tikanga. Each of these ways of knowing are critical for Maori as they inform us as to how we learn and the different ways knowledge can be acquired.

\section{Theoretical Framework}

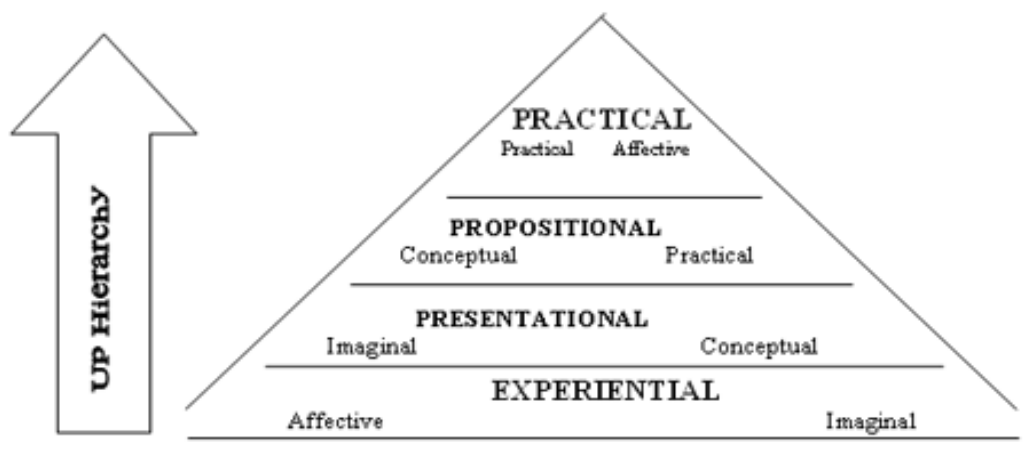

Table retrieved from (Heron \& Reason, 1997) 
Herons (1992) theory for ways of knowing are conveyed through the concept of a pyramid which he calls an "up-hierarchy". Each way of knowing has two modes of psyche with each having two processes.

Heron states that 'psyche' (as cited in Kasl \& Yorks, 2002) is "the human mind and its inherent life as a whole, including its unexpressed and unexplored potential, as well as what is manifest in conscious development" (2002, p. 2). Heron (1992) writes that the four modes of psyche are affective, imaginal, conceptual and practical, with each having two processes which are connected to his four ways of knowing. Herons theory acclaims feelings as the basis from which other characteristics of psyche materialise; being emotion, intuition, imaging, reason, discrimination, intention and action.

These systems of knowledge are often unfounded in a scientific manner, yet Bawden (1991) and Heron (1992) offer a valuable foundation for having Maori knowledge authenticated, in a way in which can be understood in European education.

\begin{tabular}{|c|c|c|}
\hline Ways of Knowing & Psyche Modes & The two related Psyche Processes \\
\hline \multirow[t]{2}{*}{ Practical Knowledge } & Affective & Feelings and Emotion \\
\hline & Practical & Intention and Action \\
\hline \multirow[t]{2}{*}{ Propositional Knowledge } & Conceptual & Reflection and Discrimination \\
\hline & Practical & Intention and Action \\
\hline \multirow[t]{2}{*}{ Presentational Knowledge } & Imaginal & Intuition and Imagery \\
\hline & Conceptual & Reflection and Discrimination \\
\hline \multirow[t]{2}{*}{ Experiential Knowledge } & Affective & Feelings and Emotion \\
\hline & Imaginal & Intuition and Imagery \\
\hline
\end{tabular}

Table retrieved from (Heron \& Reason, 1997)

Heron (1992) explains that each way of knowing must be understood in its own capacity yet each way of knowing is dependent on the ways of knowing that grounds it. For Maori this system of knowing can encapsulate our essence of being, promoting a way of knowing that is not just theoretical - but a lived, felt and experienced way of knowing the world. Epistemic cognition engages us in knowing about the way we know and come to understand the world. 


\section{Sub systems of Knowing}

Learning as a system must operate within sub-systems of learning, known as levels of learning (Bateson, 1972). Bawden (1991) provides Kitchener (1983), Salner (1986) and Perry (1970) as primary sources for systems of learning. Their synchronised information provides depth to ways of learning, through a three tier approach to 'levels of cognitive processes' (Kitchener, 1983);

Cognition $=$ Knowing

Meta Cognition $=$ Knowing about knowing

Epistemic Cognition $=$ Knowing about the nature of knowing

Bawden inform us that this three-tier approach means that in order to move from what we know, we need to understand how we know it, and this can only occur when we consciously explore at an epistemic level. Salner states that, "the development of epistemic competence is crucial for general systems of learning" (as cited by Bawden, 2005, p. 5).

Understanding epistemic cognition is vital to understanding how constraints such as status, are used as a power to restrain matauranga Maori. Status is constructed socially, a system where the dominant or oppressor's knowledge represents the norm (Johnston, P. 1998).

For Maori women, status in relation to social construction has been influenced by the notion of gender, which in turn has negatively impacted upon our perceived role and position within society (Pihama, 2001). The role and position of Maori women has been reinterpreted through western idealism in the attempt to assimilate us (Johnston, P., 1998). Through epistemic cognition we begin to understand the constraints of socially influenced knowledge enabling us as Maori women to push forward in reasserting our position as mana wahine (Pihama, 2001). Cognitive change informs divergent thinking, which in turn begins to question the influences of status as a power to constrain our knowledge as Maori.

The three-tiered cognitive approach (Perry, 1970) is applied to the understanding from which Bawden draws his levels of 'praxis for being';

Praxis $=$ Learn to be

Meta Praxis $=$ Learn to learn to be

Epistemic Praxis = Learn the nature of being

Like cognitive processes for knowing, epistemic praxis permits us as Maori women to learn about ourselves and to legitimise our ways of life and living through re-interpreting the social construction of the way Maori women are alleged to be. By gaining legitimacy for matauranga Maori, we begin to encourage a change in social construction and perception. 


\section{Critical Learning Systems}

Bawden (1991) accords Critical Learning Systems (CLS) as a process which entails a collaborative praxis. CLS is a theory that recognises multiple ways of knowing and active methods of inquiry through participation. Bawden's theory of CLS is founded on the belief that the epistemic development of people and their experiences manifests praxis and enables critical learners. Bawden draws from all three schools of systemic;

1. The first school requires a group of people or a 'social system' to be learners who are self-reflexive through experiential learning which is transformed through experience,

2. the second school requires the process of inquiring into the world using two subsystems - experiential and inspirational and;

3. the third school calls for critical thinking and axiological development of knowing.

Bawden offers education today a way to learn through multiple systems of knowing. The epistemic dimension of his theory provides for different ways of knowing to be explicit and the calls for ethics to inform the learning process. His theory requires critical thinking, a process which can be emancipatory and transformative. In order to learn, we need to acknowledge and understand that there are different ways of knowing and different truths which are informed through society, culture, values and environments (Bawden, 2005).

When the Missionaries and the colonisers came they reinterpreted our ways and being and formed their own myth about our creation and livelihood. Tuan (1977) explains that our metaphysical being cannot be seen as myth without validity. Tuan states "Myth is not a belief that can be readily verified or proved false, by the evidence of the senses" (1977, p. 85). CLS offers us as Maori a way in which our ontological and epistemic knowledge base are validated through our axiology as Maori; tikanga.

From within a Maori worldview, our system for knowing what is right and wrong, what is good and bad is derived through tikanga. They are the customs (Mead, 2000) of Maori. This united with the beliefs and traditions of Maori assists with the creation of 'being Maori'. It is not an identity that can be defined, but one that is lived and breathed; it is a way of life.

For Maori women, what Bawden offers us as learners is the ability to know what we know through the social construct of our lives. Bawden provides a way of knowing that is informed through our world, our views and our lives. In understanding this, Maori women have the ability to have our knowledge and ways validated. For Maori women, it is our ontological truth, our epistemological belief informed through our axiology; tikanga. 


\section{What do other Theorists say?}

Place based education engages the students in community practices and activities and are informed by the communities' beliefs and social norms. It engages the student in a context that is functional and situated. It is how we learnt as Maori. Our community, livelihood and experiences informed the need and relevance of knowledge (Hohepa, 1993).

Place Based Education and a sense of belonging continue to be inadequately used in curriculum by teaching staff as they are 'poorly understood' (Bolstad, 2004). This is due to teaching staff not understanding the principles of Placed Based education. The other factor that has caused resistance is the difficulty of implementation within the current educational environment.

Both concepts, Environmental education and Place Based education, are old theories and can be attributed to Dewey and other credited researchers, such as Vygotsky' (1978) whose theory of social learning and situational learning are active agents in the successful delivery of programmes designed within the Place-Based education approach. Social and situational learning is not unfamiliar to Maori, Maori were competent in describing and internalised information with social settings (Hemara, 2000).

Today these pedagogies are being regenerated into the research of contemporary education, curriculum and practices by such authors as Gruenewald (2003), Bolstad (2004) and Bowers (2001).

Situational learning and the relationship of cognition is defined as,

"Cognitive apprenticeship supports learning in a domain by enabling students to acquire, develop and use cognitive tools in authentic domain activity. Learning, both outside and inside school, advances through collaborative social interaction and the social construction of knowledge." (Brown, Collins, \& Duguid, 1989, p.34)

Situational learning - the key principles of situational learning include;

- a genuine context or setting for the knowledge to be experienced;

- social interaction; and

- collaboration

Cognition - the key principles of cognition as defined by Bruner (1996) are that;

- there needs to be the objective to learn;

- learning needs to be constructed in a manner in which a learner can grasp the concept or knowledge; 
- material, questions and learning patterns must be sequential; and

- that it should build on old knowledge to develop new knowledge

From within a classroom environment the cognitive process should build on the subsumption theory (Ausubel, 1973), whereby the initial knowledge base of the student is identified and further developed with specific detail given to increasing the known knowledge. The concept of comparing old and new knowledge is often associated with Ausubel's theory of subsumption. The objective is to encompass theory through cognition in the classroom environment and practical through community participation. Another objective is that the student uses their current knowledge base to critically reflect in order to form their experiential knowledge, a theory defined by Bawden (1991) as "Praxis; the Essence for systems of Being".

\section{How Can Education be Transformative and Emancipative?}

Bawden writes about a change in the education system through the removal of dualism and reductionism in favour of holistic thinking. His theory behind transformation is found in the 'three dimensional phenomenon' of seeing theory, practice and praxis as interrelated aspects of learning. Previous systems of dualism and reductionism have seen the two dimensions of theory and practice as opposing forces. Bawden (1991) has produced a system (A system for ways of knowing) where there is a connectedness, where no one aspect is primary, yet each contributes to a 'dynamic system of learning'.

The work of Bawden could be instrumental in the transformation of the current education curriculum. Understanding how we as individuals know what we know enables us to understand the processes in which we learn.

Traditional forms of knowledge are not easily factored into the current Western education curriculum. Bawden's system for being encompasses beliefs, traditions and rituals that are neglected in the current curricula. Piaget (1972) and Vygotsky (1978) are both noted as writing that beliefs and traditions can affect what we learn, how it is learnt and how we determine or contextualise the information. The New Zealand education system is still yet to comprehend how tradition and beliefs influence our learning. The discrimination of the New Zealand education to implement a Maori pedagogy into the curriculum has been detrimental for Maori women and their whanau. Bawden (1991) calls for change that promotes diversity in the curriculum based on the worldviews and epistemological stand point of the learner. He calls for a change in education curriculum that promotes empowerment and collaboration. 


\section{Practical Exercises as Preferred Methods of Learning}

Another attributing factor to Bawdens pedagogy is the use of practical activities that create an experiential knowledge base and in particular what he calls 'real world experiences'. This can be associated with a Maori pedagogy as for many Maori it is a preferred methods of learning (Sharples, 1994). The importance of experiential stimuli promotes personal understanding at a level of individual growth and development through contextual relativism (Salner, 1986). For Maori how we learn about the world and our way of life is a lived experience, 'it is a real world experience' (Sharples, 1994). Today the traditional methods of learning which Maori practiced, remain relevant. The traditional values and methods of learning "can be translated into contemporary contexts" (Hemara, 2000, p. 81)

\section{Group Learning, a Preferred Method of Learning}

Hohepa (1993) tells us that group learning is a preferential technique for learning that is embraced by Maori. This is acknowledged by Bawden as a crucial component to his critical learning system, where groups create a learning sub-system. The 1988 government report on Te Kohanga Reo conferred that Maori values, beliefs and practices (tikanga) were all administered within a group learning environment (Sharples, 1994). This very pedagogy was implemented into the development of Kura Kaupapa (Sharples, 1994).

Bawden provides a system that engages the learner to learn as an individual within society and as a group learner who interacts within a wider variety of aspects and thoughts that collectively assume and determine perspective. This system of learning creates the individual as a 'being' within their society. For Maori, this is how we learn, it is how we have been raised, it is our way of life. While we are individuals, our existence is merely part of a wider picture, one that embraces our community, and for Maori that is our iwi, hapu and whanau (Smith, G., 2002).

\section{Summary}

In this chapter I have explained the significance of identity, a sense of belonging and matauranga Maori for Maori women. In concluding this chapter I have proposed that education could be a transformative tool for Maori women and presented a potential pedagogy.

For us as Maori women, what we know is that Western education was very much part of the process of imperialism, and that after the signing of the Treaty of Waitangi, colonisation took a hold of our education and our demise was inevitable. The intent was to assimilate and to integrate us, into the dominant race and their norms of the world (Johnston, 
P., 1998). Today, many Maori continue to live with the consequences of imperialism and colonisation (Pihama, 2001).

In order to assimilate, social, economic and political power was used on us through racism, sexism and cultural hegemony (Johnston, P., 1998). Western culture and their institutions were imposed upon us. Education was critical to the assimilation process and saw the Maori world view (Te Ao Maori) and Maori knowledge (matauranga Maori) being undermined in favour of Western worldviews and knowledge (Bishop, 1998).

Traditionally, education was important to Maori. Prior to birth we were installing our babies with knowledge through waiata and karakia. We had school structures and systems for learning (Best, 1934). Yet after the Missionaries, education for Maori changed, and then after colonisation, legislation started to impact and redefine our rights at a detrimental rate (Bishop R. , 1998). In fact, what happened was that Maori and Western forms of education were operating in contradiction (Hemara, 2000).

Our traditional ways of learning, where we learnt through practice, active participation and by example, was to be depleted in favour of a Western system of hierarchy of education. We were to be educated in European ways of life, to read and write, to accept theory and to be informed of fact as recognised by Western theory. Our epistemic cognition (Kitchener, 1983), our epistemic praxis (Bawden, 1991), was to be voided from the education system in favour of Western ways of knowing.

Today, as a consequence Maori traditional knowledge continues to be seen as inferior to Western knowledge within the education system of New Zealand. This remains a struggle for Maori (Pihama, 2001). The past two decades of education in New Zealand have focussed on the disparities in education between Maori and Non-Maori. Whilst there was initially a focus on Maori failure, after much challenging, theorists are now questioning whether it is Maori failing the system of whether the system is failing Maori (Hemara, 2000).

What education did for us as Maori women was to reinterpret and minimalize our 'essence of systems for being' (Bawden, 1991) through undermining our worldviews, our beliefs and our ways of knowing. As a consequence we have had to learn about a new world, a foreign world. In order to assimilate us, the Western world saw it necessary to re-educate us and to re-create our identities by telling us how to live our lives and to inform us of what was knowledge. What education did for many Maori women was to dehumanise us (Freire, 1995).

Fortunately Bawden (1991) offers a way forward, a way of educating that requires a fundamental shift in how to educate. Bawdens (1991) 'essence of systems for being' requires 
that the learner is centred in the learning process and that their values, beliefs and their way of knowing inform the teaching. He calls for education that is diverse, a system of learning that knows not one imposed truth but accepts other truths that are valid through the learner's progress of development (Bawden, 1991).

Bawdens (1991) Critical Learning System is a group learning system, one that is founded on lived experienced and existing knowledge and further developed through engaging learners in practical, propositional, presentational and experiential learning. Bawdens critical learning system is a system of learning that engages community learning and the individual as part of the learning process.

If education could be used as a tool to assimilate us, why can't it be a tool to free us? Education has already demonstrated in a negative way that it is transformative, so why can't we as Maori women create an education system that positively transforms our lives by influencing our worldviews on the education system. Becoming decolonised requires us as Maori women to understand the history of colonisation and confront it (Gruenewald, 2003). It is here that transformation takes place (Smith, L., 1999). 


\section{Chapter 6: Conclusion}

\section{Introduction}

In examining the traditional roles and responsibilities of Maori women precolonialism, I have been able to present examples of how Maori women were marginalised through colonialism and imperialism. Unpacking the past experiences and the effects those experiences had upon Maori women enables critical thinking to take place. I have provided an example of how education could be transformative and conducive to empowering Maori women.

As a Maori woman, I have chosen to work within a kaupapa Maori theoretical research framework. To describe our experiences and the effects they have had upon us, I have used a qualitative approach.

\section{Summary of Chapters}

Chapter one provided an overview of the topic, aims, key definitions and the methodology and method that were applied to this thesis. In using a kaupapa Maori methodology I have been able to tell our narrative as Maori women. I have been able to work within culturally safe boundaries.

Chapter two details my subjectivity as a Maori woman and provides an explanation as to why kaupapa Maori is the correct framework for this thesis. While ethical committee approval was not required for this thesis, when working within the confines of kaupapa Maori methodology, ethical consideration as imperative as tikanga must be upheld.

Chapter three recounts our metaphysical being, our pre-colonial existence and our role as mana wahine. A Maori world view and matauranga Maori have been used to talk of the roles and responsibilities of Maori women as mana wahine. This chapter is fundamental to understanding and linking the relevance of identity, a sense of belonging and matauranga Maori to Maori women. Traditionally Maori women were not subjected to chauvinism. Maori women and men lived a balanced life; we had respectful relationships, a livelihood that acknowledged mana wahine and mana tane.

Chapter four describes how British governance colonised us through legislation. Much of the legislation made Maori women invisible, we were nonexistent. Through imperialism (education and religion), our way of life, our worldviews, belief system and knowledge were weakened and made inferior to what was supposedly a superior way of knowing and living in the world. Maori women were further marginalised through the hierarchical system of patriarchy, a system that denied wahine their status as mana wahine. 
The fifth chapter provides a rationale as to why identity, a sense of belonging and matauranga Maori are crucial to Maori women. The final part of this chapter offers a pedagogy that could assist Maori women in becoming decolonised.

\section{Research Aims Reviewed}

At the start of this journey I proposed to answer how education can contribute to liberating Maori women. In doing this there were three focus areas for research. The focus areas for this thesis were:

\section{The historical role and responsibilities of Maori women;}

Chapter three explored the roles and responsibilities of Maori women from within the metaphysical realm, the pre-colonial lives of Maori women and Maori women as leaders, both traditionally and in more contemporary times. Through describing the social construction of the Maori world view, the lived experiences of Maori women have been explored. Literature informs us that Maori men and women lived balanced and respectful lives that contributed to the communal way of living (Mikaere, 2003).

Maori women were certainly significant in the metaphysical realm, with Papatuanuku having a pivotal role in Te Ao Maori, as earth mother, as the bearer of children and as our nurturer. Papatuanuku is the woman that we come from, a woman who nurtures and sustains us and a woman that we return to; she is our beginning and our end.

The traditional role of Maori women was valued. Maori women we were the bearers of the future generations, we held and transmitted matauranga Maori in accordance with Te Ao Maori. We were responsible as leaders, as educators and on the marae. Maori women had roles that saw us as important to the collective livelihood of whanau, hapu and iwi (Pihama, 2001).

Maori women are crucial sources of knowledge. Maori women were whare tangata (house of the people) and whare matauranga (possessors of knowledge) and were fundamental to understanding the roles and responsibilities which we hold.

2. The impact in which colonisation and imperialism had upon Maori women;

A descriptive and analytical approach to writing chapter four enabled the social perception and differing worldviews of Maori and the European to be analysed. This analysis identified how Maori women were often made invisible and at times pushed to the outside of society (Pihama, 2001).

A two-prong approach was taken in writing this chapter. Colonisation was used to impose change after the establishment of New Zealand under the British and, imperialism 
was used to impose change prior to the establishment of British sovereignty, when the missionaries and traders were establishing political and economic systems in New Zealand.

The effects of legislation that marginalised Maori women was significant to the colonising affect that the British had on Maori women (Seuffert, 2005). Imperialism entailed the educational and religious influence that commenced in New Zealand prior to the British crown being established. Imperialism bought with it socially construed ideas of how Maori should exercise spiritual or religious beliefs and how they should be educated. For Maori women, our way of educating, our spiritual beliefs and our knowledge base was ignored in favour of a Western social construction of gender and race bias (Johnston \& Pihama, 1993).

While colonisation and imperialism attempted to eradicate our mana as Maori women, we nevertheless demonstrated our resilience and have continued to pass on our knowledge. Yet for some, colonisation and imperialism distorted their lives and misled their Indigenous way of life and knowing as mana wahine. Maori women were treated as second class citizens and in some cases made invisible. Processes of colonisation ignored the claims of Maori women even when some were recognised as rangatira in their own right.

3. How education can be a transformative tool in contributing to the future aspirations of Maori and in particular, Maori women.

Chapter five provides an insight into the importance of identity, a sense of belonging and matauranga Maori for Maori women. In understanding the relevance of each component and how it informs our being, an educational pedagogy is provided.

The use of Bawden was central to the pedagogy with the support of other theorists. In answering the question, how can education be a transformative tool in contributing to the future aspirations of Maori women? It becomes obvious; education has already demonstrated its transformative nature. Through colonisation and imperialism education has proven negatively its transformative capability. Education is a transformative tool. While we have seen it implemented in a damaging light, Maori women need to resist the negativity and apply education as a tool to liberate and empower us.

In order to become decolonised as accorded by

(2005) we are required to unpack our past and the effects it has had on us. Bargh (2007, p. 15) asserts that is requires "dismantling colonial structures" that have been "contaminated by colonial practices". Thereby, in understanding this, we can make choices about how we become decolonised (Smith, L., 2005) or resist the past and continued practices of imperialism and colonisation. It is with this in mind that I offer education as a transformative tool to resistance. 


\section{Summary}

As demonstrated in this thesis, the destructive processes of colonisation and imperialism saw Maori women being marginalised through legislation, education, religion and the newly settling society's perceptions of how Maori women should be and live (Mikaere, 2003).

Maori women in their traditional roles pre-European contact were respected as mana wahine, just as Maori men were respected as mana tane. Maori women and their men lived lives influenced by our epistemological beliefs. We were in balance with each other and with our environment. We were connected. Undertaking this journey to define how Maori women were made inferior and sometimes indistinguishable has been important to me as a Maori woman (Pihama, 2001).

Understanding how it happened and what instruments were applied to marginalise us allows us as Maori women to push back or as quoted, "If marginalisation is about being pushed away from the centre, then it is timely that we pushed back" (Ormond, et al., 2006, p. 194).

As we have seen in our own lives as Maori women, education can be transformative (Smith, G., 1997). In writing this thesis and providing an analysis of how education could contribute to emancipating Maori women, I hope that other people contemplating undertaking research consider alternative educational pedagogies that aid us all as Maori to live balanced lives.

Through writing this thesis, I opt to resist marginalisation and choose to push back. In doing so, I hope to offer a contribution to research that supports Maori women taking control of their destiny. 


\section{Glossary of Terms}

This glossary represents the translation of Maori to English words and has been sourced through The Reed dictionary of modern Maori (Ryan, 1995).

\begin{tabular}{|c|c|}
\hline Ahi Kaa & $\begin{array}{l}\text { The burning fires of occupation - title to land through occupation by } \\
\text { a group, generally over a long period of time. }\end{array}$ \\
\hline Aotearoa & Now used as the Maori name for New Zealand \\
\hline Ariki & $\begin{array}{l}\text { A paramount chief, high chief, chieftain, lord, leader, aristocrat, first- } \\
\text { born in a high ranking family }\end{array}$ \\
\hline Aroha & Affection, sympathy, charity, compassion, love and empathy \\
\hline Haka & $\begin{array}{l}\text { Performance of dance - vigorous dances with actions and } \\
\text { rhythmically shouted words. }\end{array}$ \\
\hline Hapu & $\begin{array}{l}\text { To be pregnant, conceived in the womb or the relationship of the } \\
\text { wider family }\end{array}$ \\
\hline Hongi & The pressing of noses in greeting \\
\hline Hui & The gathering, meeting, assembly, seminar or conference \\
\hline Iwi & $\begin{array}{l}\text { The extended kinship group, tribe, nation, people, nationality, race - } \\
\text { often referring to a large group of people descended from a common } \\
\text { ancestor }\end{array}$ \\
\hline Kaikaranga & $\begin{array}{l}\text { The caller - the woman (or women) who has the role of making the } \\
\text { ceremonial call to visitors onto a marae, or equivalent venue, at the } \\
\text { start of a powhiri. The term is also used for the caller(s) from the } \\
\text { visiting group who responds to the tangata whenua ceremonial call. } \\
\text { Traditionally this role was based on one's status within the hapu or } \\
\text { whanau, the eldest sister normally being given the role. Skilled } \\
\text { kaikaranga are able to use eloquent language and metaphor and to } \\
\text { encapsulate important information about the group and the purpose } \\
\text { of the visit }\end{array}$ \\
\hline Kainga & Home, address, residence, village, habitation or habitat \\
\hline Kaitiaki & A trustee, minder, guard, custodian, guardian, keeper \\
\hline Karakia & $\begin{array}{l}\text { Chants recited rapidly using traditional language, symbols and } \\
\text { structures. Also a prayer }\end{array}$ \\
\hline Karanga & $\begin{array}{l}\text { The formal call, ceremonial call - a ceremonial call of welcome to } \\
\text { visitors onto a marae, or equivalent venue, at the start of a powhiri. }\end{array}$ \\
\hline
\end{tabular}




\begin{tabular}{|c|c|}
\hline & $\begin{array}{l}\text { The term is also used for the responses from the visiting group to the } \\
\text { tangata whenua ceremonial call }\end{array}$ \\
\hline Kaumatua & Refers to an adult, elder, elderly man, elderly woman, old man \\
\hline Kaupapa & $\begin{array}{l}\text { Topic, policy, matter for discussion, plan, scheme, proposal, agenda, } \\
\text { subject, programme or theme }\end{array}$ \\
\hline Kawa & Marae protocol - customs of the marae and wharenui \\
\hline Kohanga Reo & $\begin{array}{l}\text { Today a Maori language preschool, traditionally is was the nesting } \\
\text { place for children }\end{array}$ \\
\hline Korero & To tell, say, speak, read, talk or address \\
\hline Kuia & An elderly woman, grandmother, female elder \\
\hline Mana tane & Men's rights \\
\hline Mana wahine & Women's rights \\
\hline Manaakitanga & Hospitality \\
\hline Manuhiri & The visitors or guests \\
\hline Maori & Indigenous New Zealander/ Aotearoa \\
\hline Marae & $\begin{array}{l}\text { The open area in front of the wharenui, where formal greetings and } \\
\text { discussions take place. Often also used to include the complex of } \\
\text { buildings around the marae }\end{array}$ \\
\hline Matauranga Maori & $\begin{array}{l}\text { Maori knowledge - the body of knowledge originating from Maori } \\
\text { ancestors, including the Maori world view and perspectives, Maori } \\
\text { creativity and cultural practices }\end{array}$ \\
\hline Mihi & A speech to greet, pay tribute, acknowledge and/or thank \\
\hline Noa & To be free from the extensions of tapu, ordinary or unrestricted \\
\hline Oronga & Umbilical cord or link to the child \\
\hline Pakeha & New Zealander of European descent \\
\hline Papatuanuku & $\begin{array}{l}\text { Earth mother and wife of Rangi-nui. All living things originate from } \\
\text { them }\end{array}$ \\
\hline Pepeha & Proverb, boast, witticism or motto \\
\hline Powhiri & Welcome, invitation, opening ceremony \\
\hline Ranginui & Sky father, refer to Papatuanuku \\
\hline Tangata whenua & Local people, aborigine, native \\
\hline Tangihanga & Mourning \\
\hline Taniko & Embroidered boarder, braid, tapestry \\
\hline
\end{tabular}




\begin{tabular}{|c|c|}
\hline Tapu & Sacred, forbidden, confidential, taboo \\
\hline Te Ao marama & The birth canal \\
\hline Te korekore & The waning moon, sterile, torn, scarcity, no activity \\
\hline Te reo & The Native language to New Zealand \\
\hline Te po tipu & The night of growth or the dark night. \\
\hline Tikanga & The custom, obligations and conditions \\
\hline Taonga & Property or treasure \\
\hline Tohunga & $\begin{array}{l}\text { Skilled person, chosen expert, priest-a person chosen by the agent of } \\
\text { the atua and the tribe as a leader in a particular field because of signs } \\
\text { indicating talent for a particular vocation }\end{array}$ \\
\hline Tupuna & $\begin{array}{l}\text { Ancestors, grandmother, great grandmother, grandfathers, great } \\
\text { grandfathers, great uncles }\end{array}$ \\
\hline Turangawaewae & $\begin{array}{l}\text { The place to stand or position, situation, site, foundation and soak or } \\
\text { steep in water }\end{array}$ \\
\hline Wairua & Spirit, soul, quintessence-spirit of a person which exists beyond death \\
\hline Whaikorero & $\begin{array}{l}\text { Formal speeches usually made by men during a powhiri and other } \\
\text { gathering }\end{array}$ \\
\hline Whakapapa & A family tree and the connection of being part of mother earth \\
\hline Whakatauki & A proverb or saying \\
\hline Whanau & $\begin{array}{l}\text { The extended family, family group, a familiar term of address to a } \\
\text { number of people, sometimes used to include }\end{array}$ \\
\hline Whanaungatanga & $\begin{array}{l}\text { The relationship, kinship, sense of family connection-a relationship } \\
\text { through shared experiences and working together which provides } \\
\text { people with a sense of belonging }\end{array}$ \\
\hline Whare Kohanga & A building erected for childbirth \\
\hline Whare kura & A school-traditionally the place where esoteric lore was taught \\
\hline Whare matauranga & The house of education, knowledge, wisdom, understanding and skill \\
\hline Whare tangata & Refers to the ability of the womb to house future generations \\
\hline Whare Wananga & $\begin{array}{l}\text { University, place of higher learning-traditionally, places where } \\
\text { tohunga taught the sons of rangatira theirs peoples knowledge of } \\
\text { history, genealogy and religious practices }\end{array}$ \\
\hline Whenua & Country, land, nation or the placenta, afterbirth \\
\hline
\end{tabular}




\section{Bibliography}

Ausubel, D. (1973). The Maori: A study in resistive Acculturation. In S. Webb (ed), \& J. Collette (ed), New Zealand Society Contemporary Perspective. Griffin Press.

Ballara, A. (1998). Iwi: the dynamics of Māori tribal organisation from c.1769 to c.1945.

Wellington: Victoria University Press.

Bargh, M. (2007). An Indigenous response to neoliberalism: Resistance. Wellington: Huia Publishing.

Barnes, H. (2000). Kaupapa Maori: Explaining the ordinary. Whariki Research Group, Alcohol \& Public Health Research Unit, University of Auckland.

Bateson, G. (1972). Steps to an ecology of mind. New York: Balentine.

Bawden, R. (2005). Systemic development at Hawkesbury: Some personal lessons from experience. System Research and Behavioural Science, 151 - 164.

Bawden, R. (1991). The essence of systems for being. HERDSA papers: Vol 14, 1-7.

Best, E. (1954). Some Aspects of Maori Myth and religion. Wellington: Government Printer.

Best, E. (1934). The Maori as he was - A brief account of Maori life as it was in Pre European days. Wellington: Dominion Museum.

Binney, J. (2006). In-Between Lives: Studies from within a colonial society. In Ballantyne, \& M. (Eds), Disputed Histories - Imagining New Zealands past (pp. 93-118). Dunedin: Otago University Press.

Binney, J. (1984). Myth and Explanation in the Ringatu tradition: Some aspects of the leadership of Te Kooti Arikirangi Te Turuki and Rua Kenana Hepetipa. Journal of the Polynesian Society, 345-398.

Bishop, R. (1998). Freeing ourselves from neo-colonial domination in research: A Maori approach to creating Knowledge. Qualitative Studies in Education , 11. No.2, 199219.

Bishop, R. (1996). Collaborative research stories: Whakawhanaungatanga. Palmerston North: Dunmore Press.

Boast, R., Erueti, A., McPhail, D., \& Smith, N. (2001). New Zealand Law Commission Mäori Custom and Values in New Zealand Law. In Maori Land Law (Vols. 4,28). Wellington: Butterworth.

Bolstad, R. (2004). Environmental education: A place in the Curriculum. New Annual Review of Education, 215-235. 
Borrell, B. (1995). Living in the City Ain't So Bad: Cultural Diversity of South Auckland Rangatahi. Massey University: A thesis submitted in partial fulfilment of a Masters of Philosophy in Psychology.

Bourdieu, P. (1971). The Berber House, or the world revisited. In J. Pouillan, \& P. Maranda, Exchanges et Communications: Melanges offerts a Claude Levi-Strauss a l'occasion de son 60eme anniversaire (pp. 151-169). Hague. Mouton.

Bowen, G. (2005). Preparing a qualitative research-based dissertation: Lessons Learned. The Qualitative Report Volume 10, No.2 , 208-222.

Broughton, J. (1993). Being Maori. New Zealand Medical Journal , 505-508: 106 (1968).

Brown, J., Collins, A., \& Duguid, P. (1989). Situated Cognition and the culture of learning. Educational Researcher, 32-42.

Cameron, J. (2004). Some implications of Malpas' Place and Experience for place ethics and education. Environmental and Architectural phenomenology , http://www.arch.ksu.edu/seamon/Cameron_malpas.htm. Retrieved 16/10/06.

Carter, L. (2005). Naming to Own: Place names as Indicators of Human interaction with the environment. Alternative - An international Journal of Indigenous Scholarship , 8.

Cieskowski, V. (1838). Prolegomena zur historiosophie. Berlin.

Clayton, P. (1996). Imperialism and Colonialism. In Enemies and Passing friends (pp. 932). Glasgow: Pluto Press.

Coney, S. (1993). Standing in the Sunshine - A history of New Zealand and Women since the won the vote. Adelaide: Griffin Press.

Cotterill, P., \& Letherby, G. (1994). The 'Person' in research. Qualitative methods Vol 4 , 107-136.

Cram, F. (2001). Rangahau Maori: Tona tika, Tona pono - The validity and integrity of Maori research. In M. Tolich, Research ethics in Aotearoa/New Zealand. longman.

Cresswell, J. (1994). Research Design: Qualitative and Quantitave Approaches. Thousand Oaks, California: USA: Sage Publications.

Cronbach, L. J. (1975). Beyond the two disciplines of scientific psychology. American Psychologist, 116-127:30(2).

Dakin, J. (1996). Looking back. In The Fourth Sector-Adult and Community Education in Aotearoa, New Zealand (pp. 21-37). Australia: Dunmore Press.

Denzin, N., \& Lincoln, Y. (1984). Handbook of Qualitative Research. Newbury Park: Sage Publications. 
Durie, M. (1998). Te Mana Te Kawanatanga: The Politics of Maori self determination. Auckland: Oxford University Press.

Durie, M. (1994). Whaiora: Maori health development. New Zealand: Oxford University Publishing.

Durkheim, E. (1997). The Division of Labor in Society (transcribed by Lewis A Coser). New York: Free Press.

Eisner, E. W. (1991). The enlightened eye: Qualitative inquiry and the enhancement of educational practice. New York: MacMillan Publishing Company.

Erickson, F. (1984). What makes school ethnography 'Ethnographic'? Antropology and Education Quarterly, 51-66.

Evans, R. (1994). The negation of powerlessness: Maori feminism a perspective. Hecate, 53.

Firth, R. (1972). Economics of the New Zealand Maori. Wellington: Government Printer: A.R Shearer.

Foucault, M. (1964). Madness and Civilization: A History of Insanity in the Age of Reason. America: Pantheon Books.

Frame, A. (1981). Colonising Attitudes towards Maori Custom. The NZ law Journal , 106110.

Freire, P. (1995). Pedagogy of the Oppressed. New York: Continuum.

Gallagher, S. (2003). A Curious document: Ta Moko as pre european textual culutre in New Zealand. BSANZ Bulletin, 39-47.

Gardiner, W. (2005). Haka - A living tradition. Auckland: Brebner Print.

Gramsci, A. (1971). Selections from the Prison Notebooks. Lawrence and Wishart.

Grey, G. (1906). Polynesian Mythology and Ancient traditional history of New Zealanders. New York: George Routledge and Sons Ltd.

Gruenewald, D. (2003). The Best of both worlds: A criticial pedagogy. Educational Researcher, 32 (4) , 3-12.

Hemara, W. (2000). Maori Pedagogies: A view from the literature. Wellington: NZCER .

Henare, M. (1998). Koru of Maori Ethics. Auckland: University of Auckland.

Heron, J. (1992). The Psyche and its world In J. Heron, Feeling and Personhood (pp. 157180). Newbury Park, CA: Sage.

Heron, J., \& Reason, P. (1997). A Participatory Inquiry Paradigm. Qualitative Inquiry , 274294. 
Heuer, B. (1969). Maori women in traditonal family and tribal life. The Journal of the Polynesian Society, 448-494.

Hohepa, M. (1993). Preferred pedagogies and languge interaction in Te Kohanga Reo. Monograpghs for the reasearch unit for Maori education. MA Thesis, Education Department, University of Auckland

hooks, b. (1994). Teaching to transgress: Education as a practice of freedom. New York: Routledge.

Hudson, M. (2004). A Maori perspective on ethical review in Health research. Tikanga Rahahau - Matauranga tuku iho . Traditional Knowledge and Research Ethics Conference.

Hughes, C. (2003). Disseminating qualitative reaserch in educational settings. England: MCGraw-Hill International .

Ihimaera, W. (2000). Women far walking. Wellington: Huia Publishing.

Irwin, K. (1994). Maori research methods and processes: An exploration. SITES - 28 , 2543.

Jackson, M. (1995). Justice and Political Power: Reasserting Maori Legal Processes. In Hazlehurst, Legal Pluralisms and the Colonial Legacy: Indigenous expereinces of Justice in Canada, Australia and New Zealand. Avebury: Aldershot.

Jenkins, K., \& Mountain Harte, H. (2011). Traditional Maori Parenting: An Historical review of literature of traditional maori child rearing practices in pre-european times. Te Kahui Mana Ririki. Auckland

Johnston, K. (2005). Maori confront discrimination: Using international human rights law to challenge discriminatory practices. Indigenous law journal , 19-69.

Johnston, P. (1998). He Aro Rereke: Education Policy and Maori underachievement: Mechanisms of Power and Difference. Unpublished Doctor of Philosophy thesis: University of Auckland.

Johnston, P., \& Pihama, L. (1993). What counts as Difference and What differences count: Gender, Race and the Politics of Difference. NZARE Conference. University of Waikato.

Kasl, E., \& York, L. (2002). An extended epistemology for transformative learning theory and its application through collaborative inquiry. Retrieved August 1st, 2010, from tc Records.org: www.tcrecord.org

Kelsey, J. (1993). Rolling back the State: The Privatisation of Power in Aotearoa/New Zealand. Wellington: Bridget Williams Books. 
Kelsey, J. (1984). Legal imperialism and the Colonization of Aotearoa. In P. Spoonley, C. Mcpherson, Pearson, \& C. Sedgwick, Tauiwi (pp. 20-43). Palmerston North: Dunmore.

King, M. (1973). Moko. Te Ao Hou The Maori Magazine.

Kiro, C. (2000). Maori Research and the Social services - Te Puawaitanga o te tohu. In Social Work Review (pp. 26-32). New Zealand.

Kitchener, K. (1983). Cognition, meta cognition and epsitemc cognition: A three level model of cognitive processing. Human Development, 222-232.

Korpela, K. (1989). Place identity as a product of environmental self regulation. Journal of Environmental Psychology , 241-256.

Kupenga, V. (1990). Whaia te Iti Kahurangi: Maori Women reclaiming Autonomy. Puna Wairere - Essay by Maori. Wellington: New Zealand Planning Council.

Laqueur, T. (1990). Making Sex: Body and Gender from the Greeks to Freud. Boston: Harvard University Press.

Law Commission - Te Aka Matua O Te Ture. (1999). Justice - the Experiences of Maori women - Te Tikanga O te ture - Te Matauranga o Nga Wahine Maori. Wellington: Law Commission.

Leoni, G. (2009). Ma te huruhuru te manu ka rere - the formation of Maori identity in Dunedin high schools. Otago: University of Otago.

Littlefield, A., Lieberman, L., \& Reynolds, L. (1982). Redefining race: The potential demise of a concept in physical anthropology. Current Anthropology, 23 , 641-655.

Mahuika, A. (1975). Leadership: Inherited and Achieved. In M. King, The world moves on: Aspects of Maoritanga. Wellington: Hicks Smith.

Marsden, M. (2003). The unwoven universe: Selected writings of Rev. Maori Marsden. Masterton: Printcraft 81 Ltd.

Maturana, H., \& Varela, F. (1988). The tree of knowledge. Shambhala Press.

McDonald, G. (1986). The Kiwi fights back. New Zealand: Raven Press.

McIntosh, T. (2003). Kanohi ki te Kanohi: Face to Face, Local government and Maori. Local Parntership and Governance - research paper 6 (p. 24). University of Auckland.

Mclennen, R., Inkson, K., Dakin, S., Dewe, P., \& Elkin, G. (1987). People and Enterprises Human Behaviour in New Zealand Organisations. Australia: Harcourt Brace Jovanovich inc. 
Mead, H. (2003). Tikanga Maori. Wellington: Huia Publishers.

Mead, H. (2000, August 11-13). The Nature of Tikanga. New Zealand Law Commission , p. 16.

Mellon, C. A. (1990). Naturalistic inquiry for library science: methods and applications for research, evaluation, and teaching. New York: Greenwood.

Metge, J. (1995). New Growth From Old: the whannau in the modern world. Wellington: Victoria University Press.

Metge, J. (1990). Te Kohao o te ngira: Culture and learning. Wellington: Ministry of Education, Learning Media.

Mikaere, A. (2003). The Balance destroyed: Consequences for Maori Women of the colonisation of tikanga maori. Auckland: University of Auckland.

Mikaere, A. (1998). Collective rights and gender Issues: A Maori womens perspective. Collective Human Rights of Pacific Peoples conference.

Mikaere, A. (1994). Maori Women: Caught in the contradictions of a colonised reality. Waikato Law review: Volume 2.

Moeke-Pickering, T. (1996). Maori identity within whanau: A review of literature. Hamilton: University of Waikato.

Mullard, C. (1982). The State's response to racism. In. Ohri, Manning \& Curno (eds). Community work and racism. London: Routledge \& Kegan Paul

Nepe, T. M. (1991). Te Toi Huarewa Tipuna: Kaupapa Maori, an Educational intervention system. Auckland: Department of Education: University of Auckland.

Numulundah, F. (1998). Teachers role in transformative education. In hooks. B, Engaged pedagogy - A trangressive education for critical consciousness. Bergin \& Garvey.

Orbell, M. (1995). Maori Myth and Legend. Christchurch: Canterbury University Press.

Ormond, A., Cram, F., \& Carter, L. (2006). Researching our relations: Reflections on ethics and marginalisation. In. Alternative: An International Journal of Indigenous Scholarship - Special Supplement: Marginalisation , 180-198.

Parker, J. (2005). Frontier of Dreams - The Story of New Zealand - Into the 21 st Century 1947-2005. . Auckland: Scholastic.

Pascual-De-Sans, A. (2001). Sense of place and migratory histories. Idiotopy and Idiotope.

Penetito, K. (2005). Me Mau Kia Ita Ki Te Taukiri o Te Whanau Ma Te Whanau e tipu AiWhanau Identity and Whanau Development are interdependent . Auckland University : Masters Thesis. 
Penetito, W. (2010). Whats Maori about Maori Education? Wellington: Victoria University Press.

Pere, R. (1997). The Wheke: A celebration of infinite wisdom. Wellington: National Library of New Zealand.

Pere, R. (1988). Te Wheke: whaia te maramatanga me to aroha. In S. Middleton, Women and education in Aotearoa (pp. 6-19). Sydney: Allen and Unwin.

Perry, W. (1970). Forms of intellectual and ethical development in the college years. New York: Holt, Rinehart and Winston.

Piaget, J. (1972). The principles of genetic epistemology. London: Routledge and Kegan Paul.

Pihama, L. (2001). Tihei Mauri Ora: Honouring our voices: Mana Wahine as a Kaupapa Maori Theoretical framework. Auckland: Unpublished PhD. University of Auckland.

Pihama, L., Cram, F., \& Walker, S. (2002). Creating methodological space: A literature review of Kaupapa Maori reseach. Canadian Journal of Native Education , 30-43.

Pipi, K., Cram, F., Hawke, R., Hawke, S., Huriwai, T., Mataki, T., Milne, M., Morgan, K., Tuhaka, H., \& Tuuta, C. (2000). A research ethic for studying Maori and Iwi provider success. Auckland: The University of Auckland.

Polkinghorne, D. (2005). Language and Meaning: data Collection in Qualitative Research. Journal of Counseling Psychology:Vol 52, no.2 , 137-145.

Polkinghorne, D. (1995). Narrative configuration in qualitative analysis. In J. Hatch, \& R. Wisniewski, Life History and Narrative (pp. 5-24). London: Falmer Press.

Rangihau, J. (1975). Being Maori. In M. King, Te Ao Hurihuri, Auckland: Octopus. Auckland: Octopus.

Reason, P., \& Heron, J. (1986). Research with people: the paradigm of cooperative experiential inquiry. Person Centred review , 456-476.

Reed, A. (1983). Maori Myth and Legend. Auckland: Reed Publishing.

Rei, T. (1993). Maori Women and the Vote. Wellington: Huia Publishing.

Rewi, P. (2010). Culture: Compromise or Perish! In B. Hokowhitu, N. Kermoal, C. Anderson, A. Petersen, M. Reilly, I. Altamirano-Jimenez, et al. (Eds.), Indigenous Identity and Resistance: Researching the diverstiy of knowledge (pp. 55-74). Dunedin: Otago University Press.

Rigney, L. (1999). Internationalisation of an Indigenous anticolonial cultural critique of Research methodology and its principles. SA Review , 109-121. 
Robinson, S. (2005). Tohunga - The revival of ancient knowledge for the modern era. Auckland: Reed Publishing.

Ryan, P. (1995). The Reed dictionary of modern Maori. Auckland: Reed Publishing.

Said, E. (1994). Culture and Imperialism. London: Vintage Books.

Salmond, A. (2004). Hui - A Study of Maori Ceremonial gatherings. Auckland: Reed Publishing.

Salner, M. (1986). Adult cognitive and epistemological development in systems education. Systems research, 223-232.

Saunders, E., Brabham, W., \& Ferguson, P. (1993). Inclusive Curriculum Provisions for Indigenous knowledge bases. World Indigenous peoples. Key note speech.

Schwimmer, E. (1966). The world of the Maori. Wellington: Reed Publishing.

Seuffert, N. (2005). Nation as Partnership: Law, "Race" and Gender in Aotearoa New Zealands Treaty Settlements. Law and Society review , 1-26.

Sharples, P. (1998). Kura Kaupapa Maori: Recommendation for Policy. Critical Perspectives on Education policy .

Sharples, P. (1994). Kura Kaupapa. In H. McQueen (Ed.), Education is Change - Twenty Viewpoints (p. 14). New Zealand: Bridget Williams Books.

Simon, J. (1994). Historical Perspectives on Education. In K. Jenkins, \& et. al, The Politics of Learning and Teaching in Aotearoa New Zealand (pp. 34-81). Palmerston North: Dunmore Press.

Simon, J. (1990). European style Schooling for Maori: First Century. University of Auckland: Unpublished Doctorate in Philosophy.

Skolimowski, H. (1985). The Co-operative mind as a partner of the creative evolution. First international Conference on the Mind-Matter interaction. Brazil: Universityof Estadual de Campinas.

Smart, C. (1992). The Women of Legal Discourse - Social and Legal Studies. Warwick: University of Warwick.

Smith, G. (2003). Kaupapa Maori: Theorising Indigenous Transformation of Education and Schooling. Kaupapa Maori Symposium: NZARE/AARE Joint Conference. Auckalnd New Zealand.

Smith, G. (2002). Placed Based Education - Learning to be where we are. Retrieved from http://helicon.vuw.ac.nz

Smith, G. (1997). The Development of Kaupapa Maori theory and praxis. University of Auckland, School of Education. Auckland: Unpublished PhD thesis. 
Smith, G. (1991). Reform and Maori Educational Crisis: A Grand Illusion. New Zealand: Post Primary Teachers Association Curriculum Conference.

Smith, L. (2006). Researching the margins: Issues for Maori researchers a discussion paper. Alternative: an International Journal of Indigenous Scholarship, Special Supplement, 5-27.

Smith, L. (2005). On tricky ground: Researching the native in the age of uncertainty. In N. Denzin, \& Y. Lincoln, The Sage handbook of Qualitative Research (3rd ed) (p. 102). Sage Publication.

Smith, L. (1999). Decolonising Methodologies Research and Indigenous Peoples. Dunedin: University of Otago.

Smith, L. (1993). Getting out from Down under: Maori women, Education and the Struggles for Mana Wahine. In M. Arnot, \& Weiler, Feminism and Social Justice in Education (pp. 58-78). London: Falmer Press.

Smith, L., \& Simon, J. (2001). Pedagogies of the Native Schools. In L. Smith, \& J. Simon, A Civilising Mission? Perceptions and Representations of the New Zealand Native School System (pp. 117 - 140). Auckland: Auckland University.

Staszak, J. (2008). Other/Otherness. International encyclopedia of Human Geography .

Stewart-Harawira, M. (1993). Maori, Who owns the definition? The politics of Cultural Identity. Te Pua , 27-34.

Strum, C. (1954). The Maori womens Welfare League. In M. P. Board, Te Ao Hou - Spring. Wellington: Department of Internal Affairs.

Tauroa, H., \& Tauroa, P. (2005). Te Marae-A Guide to Customs and Protocols. Auckland: Reed Publishing.

Te Awekotuku, N. (1991). Mana Wahine Maori. Auckland: New Womens Press.

Tolich, M. (1999). Collecting Data. In C. Davidson, Social Research in New Zealand. New Zealand: Pearson Education.

Tuan, Y. (1977). Mythical space and place. In Space and place - The perspective of experience (pp. 85-100). University of Minnesota.

Vygotsky, L. (1978). Mind in Society. Cambridge: Harvard University Press.

Walker, R. (2006). Maori Conceptions of leadership and Self determination. In R. Miller, \& R. Mintron, Political Leadership in New Zealand (pp. 134-153). Aukland: Auckland University Press.

Walker, R. (1993). Inaugural Lecture-Tradition and change in Maori Leadership. Auckland: University of Auckland. 
Ward, A. (1983). A show of Justice - Racial amalgamation in nineteenth century New Zealand. Auckland: University of Auckland.

Whiu, L. (2001). Journey of Contradiction and Liberation: One Indigenous womans story. Indigenous rights in the Commonwealth: South Pacific Regional Expert Meeting. Nadi, Fiji Islands.

Williams, J. (2010). Towards a Model for Indigenous Research. In B. Hokowhitu, N. Kermoal, C. Anderson, A. Petersen, M. Reilly, I. Altamirano-Jimenez, et al. (Eds.), Indigenous Identity and Resistance: Researching the diversity of knowledge (pp. 107-124). Dunedin: Otago University Press.

Williams, J. (2000, October). The nature of the Maori community. PSSM Conference, New Zealand stage services Commission .

Wilson, M. (1993). Women and the law. In Walking backwards into the future (pp. 107119). Hamilton: Womens Electoral Lobby.

Winitana, M. (2008). Contemporary perceptions of mana wahine Māori in Australia: A diasporic discussion. MAI Review part 3 .

Wolcott, H. (1995). The art of fieldwork. Walnut Creek: Atta Mira Press. 